\title{
The novel protein kinase $C$ epsilon isoform at the adult neuromuscular synapse: location, regulation by synaptic activity-dependent muscle contraction through TrkB signaling and coupling to ACh release
}

\author{
Teresa Obis ${ }^{\dagger}$, Núria Besalduch ${ }^{\dagger}$, Erica Hurtado, Laura Nadal, Manel M Santafe, Neus Garcia, Marta Tomàs, \\ Mercedes Priego, Maria A Lanuza ${ }^{*+}$ and Josep Tomàs ${ }^{*+}$
}

\begin{abstract}
Background: Protein kinase C (PKC) regulates a variety of neural functions, including neurotransmitter release. Although various PKC isoforms can be expressed at the synaptic sites and specific cell distribution may contribute to their functional diversity, little is known about the isoform-specific functions of PKCs in neuromuscular synapse. The present study is designed to examine the location of the novel isoform nPKC $\varepsilon$ at the neuromuscular junction (NMJ), their synaptic activity-related expression changes, its regulation by muscle contraction, and their possible involvement in acetylcholine release.

Results: We use immunohistochemistry and confocal microscopy to demonstrate that the novel isoform $n P K C \varepsilon$ is exclusively located in the motor nerve terminals of the adult rat NMJ. We also report that electrical stimulation of synaptic inputs to the skeletal muscle significantly increased the amount of $\mathrm{nPKC} \varepsilon$ isoform as well as its phosphorylated form in the synaptic membrane, and muscle contraction is necessary for these $\mathrm{nPKC} \varepsilon$ expression changes. The results also demonstrate that synaptic activity-induced muscle contraction promotes changes in presynaptic nPKC $\varepsilon$ through the brain-derived neurotrophic factor (BDNF)-mediated tyrosine kinase receptor B (TrkB) signaling. Moreover, $\mathrm{nPKC} \varepsilon$ activity results in phosphorylation of the substrate MARCKS involved in actin cytoskeleton remodeling and related with neurotransmission. Finally, blocking $\mathrm{nPKC} \varepsilon$ with a $\mathrm{nPKC} \varepsilon$-specific translocation inhibitor peptide $(\varepsilon \mathrm{V} 1-2)$ strongly reduces phorbol ester-induced ACh release potentiation, which further indicates that $\mathrm{nPKC} \varepsilon$ is involved in neurotransmission.

Conclusions: Together, these results provide a mechanistic insight into how synaptic activity-induced muscle contraction could regulate the presynaptic action of the $\mathrm{nPKC} \varepsilon$ isoform and suggest that muscle contraction is an important regulatory step in TrkB signaling at the NMJ.
\end{abstract}

Keywords: PKC, PKC epsilon, Neuromuscular junction, Neurotransmission, Immunofluorescence, Electrical stimulation, Muscle contraction, TrkB

\footnotetext{
*Correspondence: mariaangel.lanuza@urv.cat; josepmaria.tomas@urv.cat

${ }^{\dagger}$ Equal contributors

Unitat d'Histologia i Neurobiologia (UHN). Facultat de Medicina i Ciències de

la Salut, Universitat Rovira i Virgili, Sant Llorenç 21, 43201 Reus, Spain
}

() Biomed Central (c) 2015 Obis et al.; licensee BioMed Central. This is an Open Access article distributed under the terms of the Creative Commons Attribution License (http://creativecommons.org/licenses/by/4.0), which permits unrestricted use, distribution, and reproduction in any medium, provided the original work is properly credited. The Creative Commons Public Domain Dedication waiver (http://creativecommons.org/publicdomain/zero/1.0/) applies to the data made available in this article, unless otherwise stated. 


\section{Background}

Protein kinase $\mathrm{C}(\mathrm{PKC})$ comprises a family of serinethreonine protein kinases highly distributed in neural and neuromuscular tissues and involved in neurotransmitter release [1-5]. PKC isoforms, referred to as conventional, novel and atypical types, are activated by phosphatidylserine, diacylglycerol and/or $\mathrm{Ca}^{2+}$. Different isoforms exhibit distinct tissue distributions and different colocalizations of an activated PKC isoform with its endogenous protein substrates contributes to the functional diversity of the PKC isoforms [6,7]. Intracellular PKC-binding proteins known as RACKs (receptors for activated C-kinase) are essential to achieve the cellular specific patterns of distribution of an individual activated PKC isoform and therefore the functions of the PKC isoforms $[8,9]$. Therefore, the mechanisms that activate and compartmentalize PKC isoforms must be identified if the physiological functions of PKC are to be better understood.

Protein kinase $\mathrm{C}$ epsilon (nPKCe), a novel PKC isoform, is involved in the regulation of diverse cellular functions. It is highly expressed in the brain and several neural functions of $\mathrm{nPKC} \varepsilon$, including neurotransmitter release, have been identified [10]. It has been shown by Western blot analysis that $\mathrm{nPKC} \varepsilon$ is also present in the skeletal muscle [11,12]. However, to date, no reports have been published on the localization and function of the $\mathrm{nPKC} \varepsilon$ at the paradigmatic neuromuscular junction (NMJ). The present study is designed to examine the distribution of $\mathrm{nPKC} \varepsilon$ at the NMJ of the adult rat and to know whether $\mathrm{nPKC} \varepsilon$ level in synaptic membrane is modulated by synaptic activity and muscle contraction.

Myristolyated alanine rich C kinase substrate (MARCKS), a neuronal signal protein abundantly expressed in nerve endings, is an actin cross-linking protein that is highly phosphorylated on serine residues after PKC activation [13-15]. In addition, $\mathrm{nPKC} \varepsilon$ regulates large dense-core vesicle release via phosphorylation of MARCKS [16]. MARCKS seems to be a key participant in actin cytoskeleton remodeling, which is the instrument to promote transfer of synaptic vesicles to the plasma membrane, relating thus MARCKS to neurotransmitter release [16-19]. Therefore, we studied if $\mathrm{nPKC} \varepsilon$ activity results in phosphorylation of the substrate MARCKS at the NMJ. Finally, we investigated the possible involvement of $\mathrm{nPKC} \varepsilon$ in ACh release.

We used immunohistochemistry and confocal microscopy to discriminate that $\mathrm{nPKC} \varepsilon$ is exclusively located in the nerve terminals at the NMJ. We also disrupted the interaction between $\mathrm{nPKC} \varepsilon$ and its specific RACK (and therefore its activation) with an isozyme-selectivetranslocation peptide inhibitor $(\varepsilon V 1-2,[20])$ in acute biochemical and electrophysiological experiments that also involved synaptic activity. We found that electrical activity-induced muscle contraction promotes changes in presynaptic $\mathrm{nPKC} \varepsilon$ level through TrkB activity and that the nPKCe catalytic activity is related to the phosphorylation of MARCKS in an activity-dependent way. The results also demonstrate that $\mathrm{nPKC} \varepsilon$ is involved in the PMA-induced ACh release mechanism at the NMJ.

\section{Results}

$\mathrm{nPKC} \varepsilon$ and pnPKC $\varepsilon$ are expressed in adult and newborn skeletal muscle

Western blot analysis using an antibody raised against the novel PKC isoform $\varepsilon$ was carried out to determine the presence of the $\mathrm{nPKC} \varepsilon$ isoform in young adult (P30$\mathrm{P} 40)$ diaphragm skeletal muscle. We also immunoblotted samples with an anti-phospho-PKC $\varepsilon$ antibody to identify the specific phosphorylation of $\mathrm{nPKC} \varepsilon$ that is a requisite for PKC catalytic activity $[21,22]$. These experiments revealed significant amounts of this isoform (Figure 1A). The antibodies used only recognized the corresponding protein, reacting with a band consistent with its predicted molecular weight (manufacturer's data sheets) (Figure 1A). No $\mathrm{nPKC} \varepsilon$ presence was observed in brain excised tissues of $\mathrm{KO}$ mice in $\mathrm{nPKC} \varepsilon$, using this antibody [23]. Like other $\mathrm{PKC}$ isoenzymes, $\mathrm{nPKC} \varepsilon$ must be primed through phosphorylation to display full enzymatic activity and respond to allosteric regulators.

We performed Western blot analysis and a quantitative study (VersaDoc, Bio Rad, Hercules, CA) to analyze

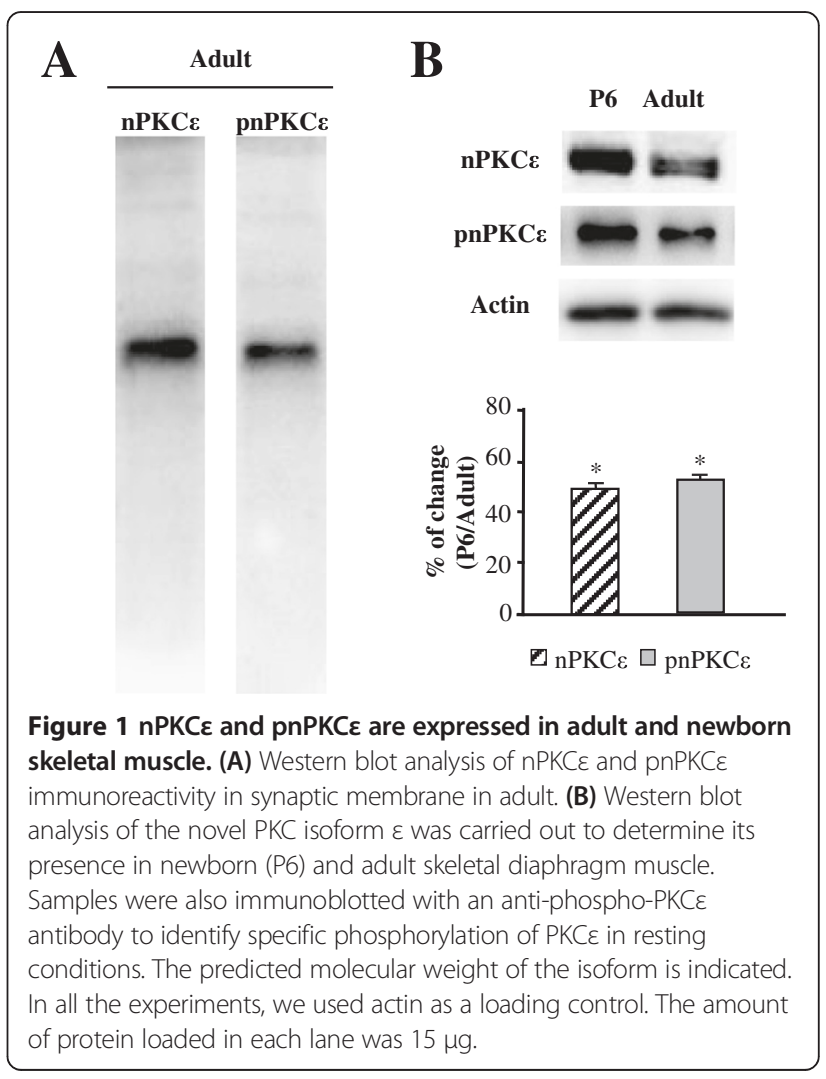


the density of the band and evaluate the relative amount of the kinase isoform (and its phosphorylated form) in both the newborn (P6) and the adult. The results show that the expression of $\mathrm{nPKC} \varepsilon$ isoform appears to be agedependent being $\mathrm{nPKC} \varepsilon$ more abundant in the newborn than in the adult (Figure 1B). Under resting conditions (isolated muscle does not receive action potentials from the motor neuron soma), we also found quite an abundant level of phosphorylated $\mathrm{nPKC} \varepsilon$ and also $\mathrm{pnPKC} \varepsilon$ is more abundant in the newborn than in the adult (Figure1B).

In conclusion, $\mathrm{nPKC} \varepsilon$ is abundantly expressed and phosphorylated in the skeletal muscle. Subsequently, immunohistochemical analyses were performed to identify the cellular localization of the $\mathrm{nPKC} \varepsilon$ isoform at the adult neuromuscular junction components (ie. muscle cells, Schwann cells or nerve terminals).

\section{nPKC $\varepsilon$ isoform is located in the nerve terminal at the neuromuscular junction}

Immunofluorescence staining coupled with confocal microscopy analysis was performed to determine the presence and localization of this isoform at the adult NMJ. Precise knowledge of the cellular localization of the ${ }_{\mathrm{nPKC}} \varepsilon$ in pre-, post- and/or perisynaptic elements is crucial for elucidating the function/s of this protein. Immunofluorescence experiments were performed in the diaphragm and LAL muscles and immunoreactivity for $\mathrm{nPKC} \varepsilon$ was identical in both muscles. All pictures in Figure 2 show intense immunoreactivity for $\mathrm{nPKC} \varepsilon$ in the synaptic area identified with AChR labeling. Figure $2 \mathrm{~A}$ shows a NMJ with double labeling: AChRs in red and $\mathrm{nPKC} \varepsilon$ in green. Figure 2B shows a NMJ with triple labeling: AChRs in red, the Schwann cell in blue and $\mathrm{nPKC} \varepsilon$ in green. These figures show $\mathrm{nPKC} \varepsilon$-positive green immunolabeling concentrated at the presynaptic position over the red postsynaptic gutters (asterisks). This can be seen both in the semiconsecutive confocal sections (A2-4, B2-4) and in the maximum projection (A1, B1) from the NMJs. The glia and muscle cell do not seem to be labeled (Figure 2B). In Figure 2A, it appears that pre-terminal axon is also nPKCe-positive.

To improve the analysis of the cellular distribution of the kinase at the NMJ we obtained semithin crosssections from whole-mount multiple-immunofluorescent stained muscles [24]. We performed a triple staining in which $\mathrm{nPKC} \varepsilon$ isoform (in green in Figure 2C2) was colocalized with molecular markers of the three cellular elements in the NMJ: muscle cell (nAChR marked with fluorescently labeled $\alpha$-bungarotoxin, in red, Figure 2C3), Schwann cell (S-100, in blue, Figure 2C4) and nerve terminal (syntaxin and neurofilament, in blue, inset in $\mathrm{C} 1$ ) (Figure 2C). When the $\mathrm{nPKC} \varepsilon$ was co-stained with $\alpha$ BTX and S-100 (C1, colocalization picture), the nPKCe immunofluorescence (in green) was shown as several small granular areas located over the postsynaptic line of the nAChRs (in red) and externally surrounded by the Schwann cell (in blue). This label corresponds to the axonal buttons of the nerve terminal because it is colocalized with the syntaxin/neurofilament stain (labeled in blue in the inset in $\mathrm{C} 1$, Figure $2 \mathrm{C}$ ) and also with syntaxin alone (not shown). Thus, the results indicate that $n P K C \varepsilon$ has a unique location in the synapse: it is exclusively expressed in the nerve terminals at the NMJ.

Denervation of the extensor digitorum longus muscle (EDL) was performed to confirm that $\mathrm{nPKC} \varepsilon$ is located in the nerve. We denervated the muscle, waited 1-3 days, and studied the level of $\mathrm{nPKC} \varepsilon$ by Western blots. The results show that $\mathrm{nPKC} \varepsilon$ protein almost completely disappear after 1 day of denervation (ratio denervated/ control $0.11 \pm 0.08, \mathrm{p}<0.05)$ indicating that the most part of $\mathrm{nPKC} \varepsilon$ is located in the nerve (Figure 2D). By contrast, cPKC $\alpha$, an isoform ubiquitously located [25], slightly decreased (Figure 2D). Syntaxin has been used as a control of denervation. The residual presence of $\mathrm{nPKC} \varepsilon$ may be related with blood vessels [11].

\section{nPKC $\varepsilon$ expression is modulated by synaptic activity}

Synaptic function of PKC family has been shown to be regulated by activity [25], so we tested whether $\mathrm{nPKC \varepsilon}$ synaptic level is modulated by synaptic activity. Therefore, we studied whether there was any change in the amount of $\mathrm{nPKC} \varepsilon$ and its phosphorylated form in the synaptic membrane after electrical stimulation (with and without muscle contraction). Electrical stimulation of synaptic inputs to the diaphragm skeletal muscle $(1 \mathrm{~Hz}$ for 30 minutes) and the resulting muscle contraction significantly increased the amount of $\mathrm{nPKC} \varepsilon$ isoform and its phosphorylated form in the synaptic membrane (Figure 3A).

To separate the effect of the presynaptic stimulation (and synaptic transmission) from the effect of the muscle cell contraction, we performed experiments in which contractions were inhibited. When the contraction was inhibited by cutting the muscle fibers [26-28] or by using $\mu$-CgTx-GIIIB $[28,29]$, the electrical stimulation significantly decreased $\mathrm{nPKC} \varepsilon$ and its phosphorylated form in the synaptic membrane (Figure 3A). Thus, nerve stimulation influences the kinase level in the synaptic membrane and this suggest that, with stimulation, the kinase could be detached from the membrane (and therefore stop its catalytic function), or alternatively stimulation entails some consumption of the enzyme. These results clearly indicate that muscle contractions induce an important change that reverses the effect of nerve stimulation by itself on $\mathrm{nPKC} \varepsilon$ level in the synaptic membrane, suggesting that muscle contraction is necessary for $\mathrm{nPKC} \varepsilon$ maintenance and its catalytic activity. Moreover, we performed several Western blots of $\mathrm{nPKC} \varepsilon$ and $\mathrm{pnPKC} \varepsilon$ to 


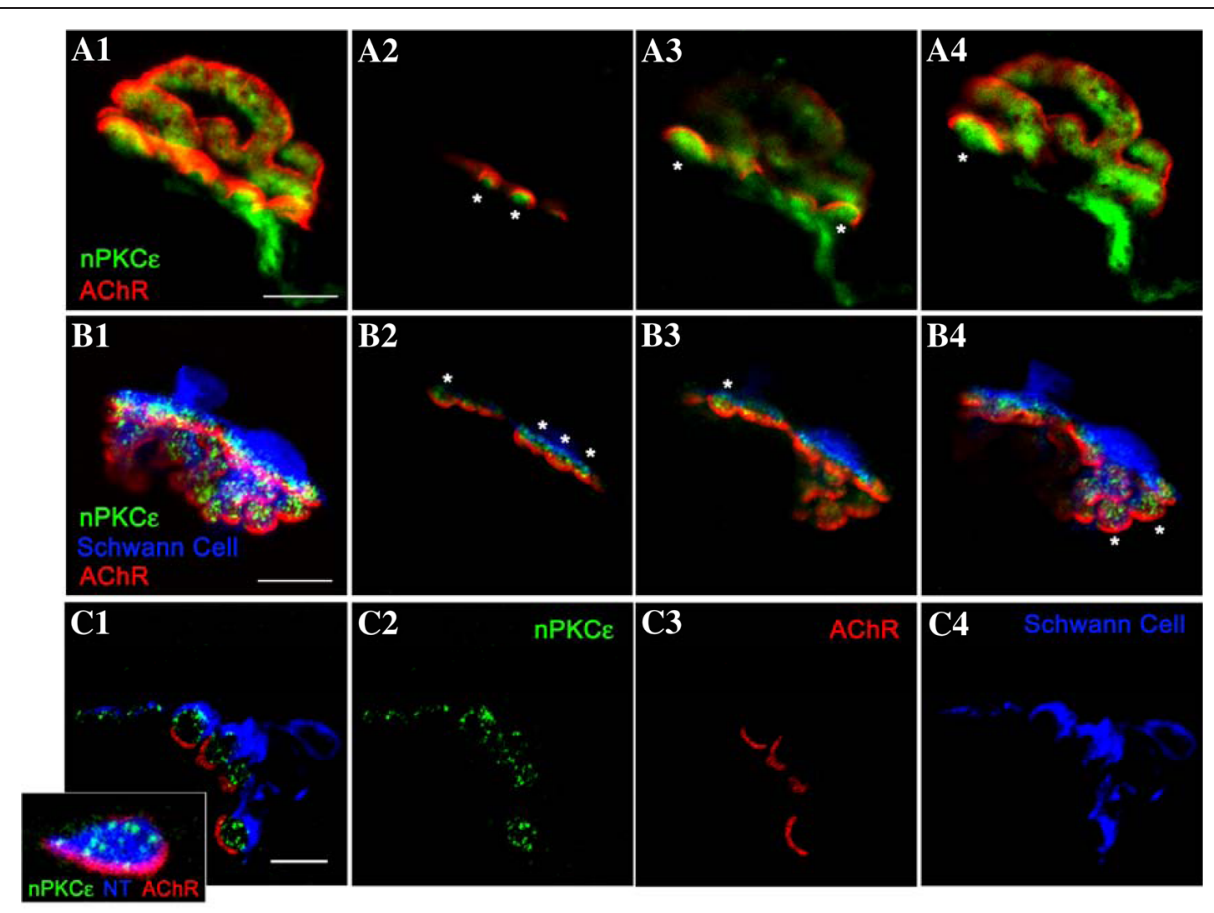

D

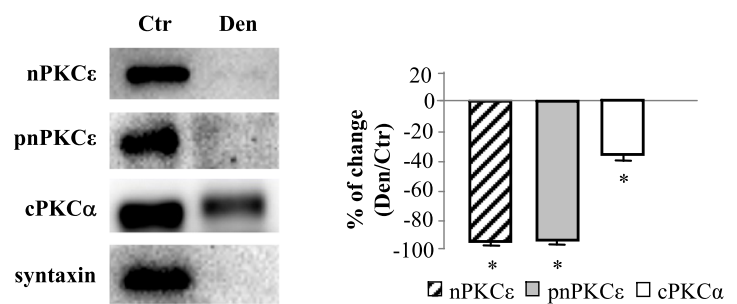

Figure $2 \mathrm{nPKC} \varepsilon$ isoform is located in the nerve terminal at the adult neuromuscular junction. (A1) shows a reconstruction of a NMJ stained for AChRs with fluorescent a-Bungarotoxin in red and immunolabeled with an antibody against nPKC $\varepsilon$ isoform in green. (A2-A4), several semiconsecutive confocal optical sections from the same NMJ shown in A1. The (*) indicates nPKC $\varepsilon$-positive nerve terminal buttons accommodated in the AChRs delimited synaptic gutters. (B1) shows a reconstruction of a NMJ triple labeled for AChRs (fluorescent a-BTX in red), the Schwann cell (immunolabeled with an anti S-100 antibody in blue) and nPKC isoform in green. (B2-B4), several confocal sections from the same NMJ shown in B1. The $\left(^{*}\right)$ also indicates nPKC $\varepsilon$-positive granular immunolabeling concentrated on the nerve endings position over the synaptic gutters. The glia and muscle cell are not labeled. (C), Immunohistochemistry in semithin sections from a whole-mount multiple-immunofluorescent stained muscle. In the colocalization picture (C1), the triple staining that labeled $\mathrm{nPKC} \varepsilon$ in green (C2), AChRs in red (C3) and Schwann cells in blue, (C4) shows the nPKC $\varepsilon$ immunolabel only in the middle of the sandwich formed by glia and muscle cell. In the inset (C1), the control triple staining that labeled PKC (in green), AChRs (in red) and the nerve terminal (NT, in blue, neurofilament-200/syntaxin) shows that the $\mathrm{nPKC} \varepsilon$ and nerve terminal markers are well colocalized. The bars in (A), (B) and (C) indicate $10 \mu \mathrm{m}$. The bar in the inset indicates $2.5 \mu \mathrm{m}$. The NMJ are from LAL muscles. (D) Western blot analysis of $n P K C \varepsilon$, pnPKC $\varepsilon, C P K C a$ and syntaxin in denervated EDL muscle.

compare the effect of the method to abolish muscle contraction (cut and $\mu$-CgTx GIIIB $(\mu \mathrm{CTX})$ ). Quantitative data show that (Figure 3B): (1) levels of $\mathrm{nPKC}$ and pnPKC $\varepsilon$ are not significantly different in cut muscles and in muscles where muscle contraction was abolished by $\mu$-CgTx GIIIB ( $\mu$ CTX); (2) nPKC $\varepsilon$ and pnPKCe significantly decreases in electrically stimulated intact muscles where muscle contraction was abolished by $\mu \mathrm{CgTx}$ GIIIB (ES/ $\mu \mathrm{CTX})$ in a similar way as occurs in electrically stimulated muscles where muscle contraction was abolished by cut (ES/Cut); (3) There are no significant differences between ratios $\mu \mathrm{CTX}$ vs Cut. These results eliminate any possible artifact due to the method used to abolish muscle contraction.

\section{Electrical activity-induced muscle contraction promotes changes in $\mathrm{nPKC} \varepsilon$ through TrkB activity}

The results set out above (Figure 3A) show that, in contracting muscles, the level of $\mathrm{nPKC} \varepsilon$ are highly increased relative to the stimulated and non-contracting muscles, but also relative to the non-stimulated muscles. The results also show that when synaptic activity is not 

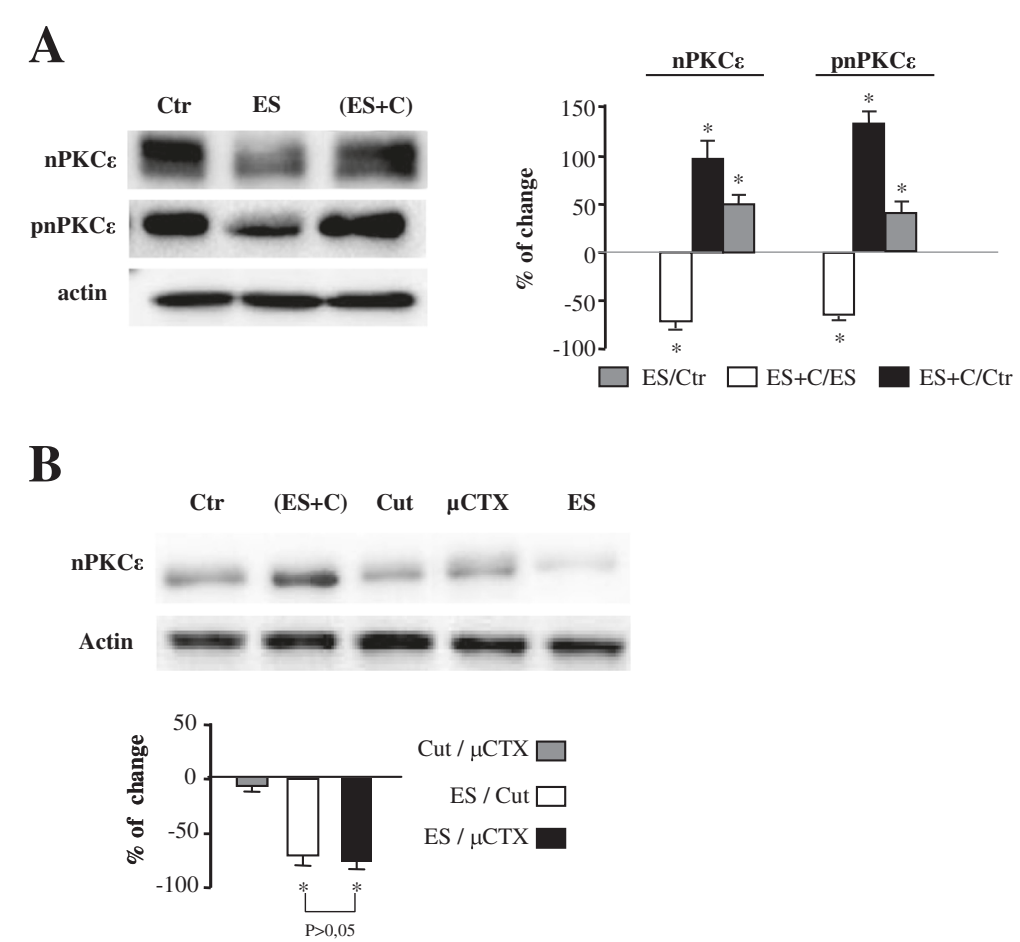

Figure 3 nPKC $\varepsilon$ expression is modulated by synaptic activity. (A) Western blot analysis of $n P K C \varepsilon$ and pnPKC $\varepsilon$ immunoreactivity levels in synaptic membrane in adult stimulated muscles with (ES $+C$ ) and without (ES) muscle contraction. (B) shows Western blots of $n P K C \varepsilon$ to compare the effect of the method to abolish muscle contraction (cut and $\mu$-CgTx GIIIB ( $\mu C T X)$ ). Quantitative data eliminate any possible artifact due to the method used to abolish muscle contraction. There are no significant differences between ratios $\mu$ CTX vs Cut. The Western blot shows: (1) levels of $\mathrm{nPKC} \varepsilon$ in non-stimulated muscles where no method was performed to abolish muscle contraction (Ctr), in cut muscles (Cut) and in muscles where muscle contraction was abolished by $\mu-C g T x$ GIIIB ( $\mu \mathrm{CTX}$ ); (2) nPKC $\varepsilon$ in electrically stimulated intact muscles where muscle contraction was abolished by $\mu \mathrm{CgTx}$ GIIIB (ES, $\mathrm{CCTX}$ ); and (3) $\mathrm{nPKC} \varepsilon$ in stimulated muscles resulting in contraction (ES + C). Experiments were performed using diaphragm muscle.

accompanied by muscle contractile activity, the level of $\mathrm{nPKC} \varepsilon$ is decreased. Thus, we hypothesize that muscle contraction induces a change that can reverse the effect of nerve stimulation itself and a contraction-dependent neurotrophic support from postsynaptic site may make a contribution to this through the tyrosine kinase receptor B (TrkB). To demonstrate whether the activation of TrkB, as a result of muscle contraction, is critical to affect nPKCE's level, we selectively suppressed TrkB activity in contracting diaphragm muscles using selective TrkB inhibitors. We used ANA-12 which showed direct and selective binding to TrkB and inhibits processes downstream of TrkB without altering TrkA and TrkC functions [30]. ANA-12 fully inhibits BDNF-induced TrkB phosphorylation and therefore prevents receptor activation. We also used an anti-TrkB antibody (47/TrkB) which effectively inhibits BDNF binding to TrkB receptors [31]. We measured resultant $\mathrm{nPKC} \varepsilon$ and $\mathrm{pnPKC} \varepsilon$ levels and found that TrkB blockade resulted in a significant decrease in the isoform (Figure 4). We obtained the same result with the two blockade methods. These results demonstrate that electrical activity-induced muscle contraction promotes increase in $\mathrm{nPKC} \varepsilon$ and $\mathrm{pnPKC} \varepsilon$ through TrkB activity suggesting that muscle contraction induce an increase of the interaction of a TrkB-specific neurothrophic factor with $\operatorname{TrkB}$ that enhance the intracellular signaling to increase the isoform levels in the synaptic membrane. Accordingly, exogenously added BDNF (10 nM, 30 minutes) in stimulated muscles without contraction significantly increased the amount of pnPKCe $(58.78 \% \pm 2.1 \%$ of change, $\mathrm{p}<0.05)$. This result indicates that exogenous BDNF mimics muscle contraction effect on nPKC $\varepsilon$ levels. We choose the BDNF dose based in a previous dose-response and time-course study in the same muscle to determine their effect on the size of the evoked EPP [32].

$\mathrm{nPKC} \varepsilon$ regulates phosphorylation of MARCKS in skeletal muscle, in an activity-dependent way

To gain insight into the role of $\mathrm{nPKC} \varepsilon$ we analyzed possible substrate phosphorylation. Although the translocation and phosphorylation of $\mathrm{PKC}$ is indicative of $\mathrm{PKC}$ activation [33], a more direct measure of the PKC activity is to detect PKC substrate phosphorylation in cells. Therefore, we wanted to know whether MARCKS phosphorylation is dependent on $\mathrm{nPKC} \varepsilon$ at the NMJ and 


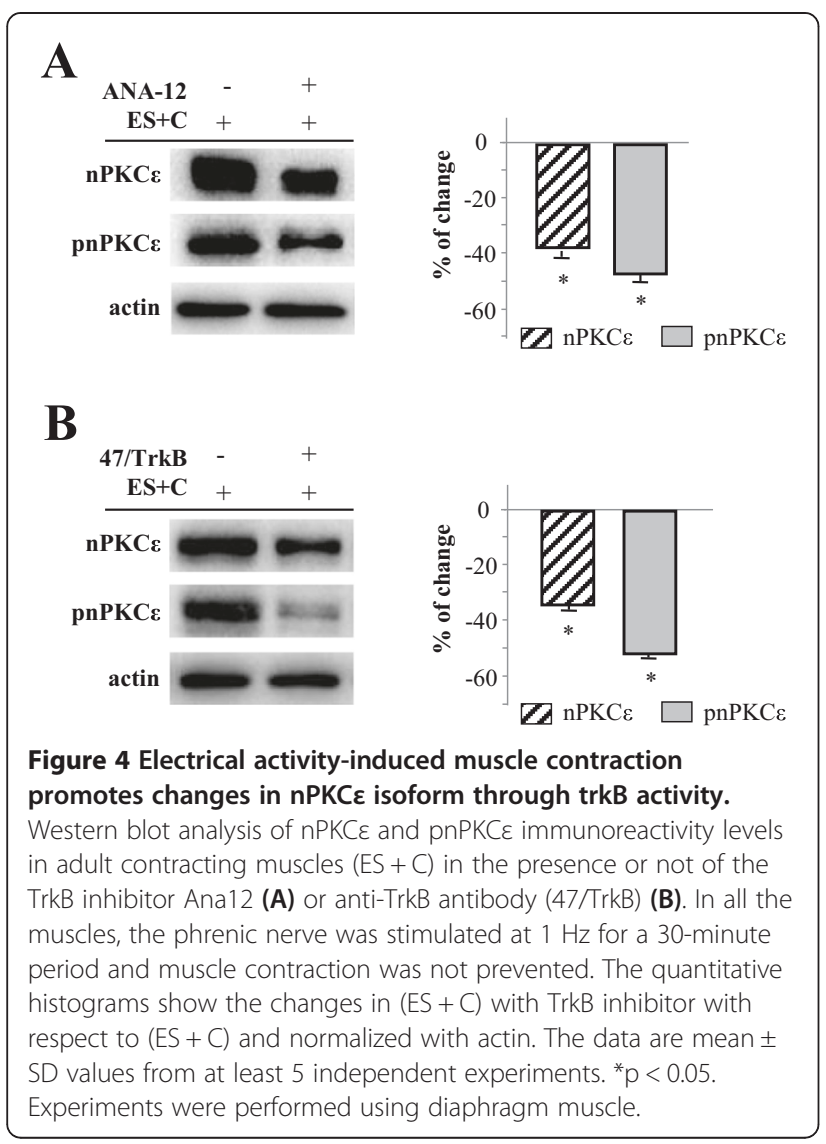

whether its phosphorylation depends on the synaptic activity (with and without muscle contraction).

We used the nPKCe-specific translocation inhibitor peptide, epsilonV1-2 (عV1-2; [20]), to block the isoform activity. We first wanted to show that the peptide $\varepsilon \mathrm{V} 1-2$ inhibits the presence of $\mathrm{nPKC} \varepsilon$ and $\mathrm{pnPKC} \varepsilon$ in the synaptic membrane of the diaphragm muscle. Figure 5A shows that incubation with the peptide $\varepsilon V 1-2(100 \mu \mathrm{M})$ produces a rapid $(10 \mathrm{~min})$ and significant decrease in $\mathrm{nPKC} \varepsilon$ and $\mathrm{pnPKC} \varepsilon$ that is maintained after 60 minutes of incubation with the peptide (not shown). This decrease in the level of the $\mathrm{nPKC} \varepsilon$ and $\mathrm{pnPKC} \varepsilon$ induced by incubation with $\varepsilon V 1-2$ suggests that the $\mathrm{nPKC} \varepsilon$ isoform may be tonically involved in some nerve terminal mechanism. No change in the level of the $\mathrm{nPKC} \varepsilon$ and $\mathrm{pnPKC} \varepsilon$ was observed in the presence of $100 \mu \mathrm{M}$ of the scrambled peptide (not shown). Furthermore, the inhibition of $n \mathrm{PKC} \varepsilon$ by the peptide has a different effect on $\mathrm{nPKC} \varepsilon$ and $\mathrm{pnPKC \varepsilon}$ (nPKCe decreases a $70 \%$ while pnPKC $\varepsilon$ a 40\%). In this context, Figure 5A also shows that Hsp70 (heat shock protein 70 ), which has a role in prolonging the lifetime of activated PKC, significantly increases in the presence of the inhibitor peptide of nPKCe. This suggests a major interaction of Hsp70 with pnPKCe, which could prolong the lifetime of active $\mathrm{nPKC} \varepsilon(\mathrm{pnPKC} \varepsilon)$ and sustain its function.

Next, we looked for pMARCKS expression in the skeletal muscle and in denervated muscle. Figure 5B shows the time course of the level of pMARCKS in diaphragm muscle in resting conditions indicating that skeletal muscle expresses pMARCKS and that pMARCKS is quite stable after muscle dissection. Denervation of EDL muscle totally removes pMARCKS (Figure 5 C) indicating its presynaptic location. Note that syntaxin, a molecule exclusively located in the presynaptic component at the NMJ that has been used as a control, also disappears after denervation.

We next studied whether MARCKS phosphorylation is dependent on $\mathrm{nPKC} \varepsilon$ in the skeletal muscle. Figure 5A shows that incubation for 10 minutes of the muscles with the peptide $\varepsilon V 1-2$ produces a significant decrease in pMARCKS indicating that $\mathrm{nPKC} \varepsilon$ is related to the phosphorylation of MARCKS in the skeletal muscle.

To determine whether stimulation (synaptic activity by itself, without muscle contraction) induces $\mathrm{nPKC} \varepsilon$ phosphorylating activity on MARCKS in skeletal muscle, we subjected the protein extracts of stimulated muscles to phospho-MARCKS immunoblotting. WB analysis shows a significant increase in pMARCKS at 10 minutes indicating that phosphorylation of MARCKS depends on synaptic activity by itself (Figure 6A). In this condition, Hsp70 is also increased suggesting that pnPKCe could be stabilized by Hsp70 and therefore the kinase placed in the membrane could continue regulating the phosphorylation of MARCKS and increasing its amount. To further relate the effects of electrical activity and $\mathrm{nPKC} \varepsilon$ activity we stimulated muscles previously incubated $(100 \mu \mathrm{M}, 30 \mathrm{mi}-$ nutes) with the blocking peptide (Figure 6B). We found a significant decrease in pMARCKS level, which emphasizes the role of nPKCE in MARCKS phosphorylation depending on the presynaptic activity. According, $\mathrm{nPKC} \varepsilon$ and $\mathrm{pnPKC} \varepsilon$ significantly decreased in these same conditions (Figure 6C) indicating also a possible additive effect and suggesting different levels in the modulation of $\mathrm{nPKC} \varepsilon$ expression. Incubation with the inactive peptide (Vs) did not modify the level of the isoform obtained with electrical stimulation (Figure 6C).

To test whether muscle contraction has an additional effect on MARCKS phosphorylation, we also analyzed pMARCKS level in electrical stimulated contracting muscles. Electrical stimulation accompanied by contraction (for 30 minutes) significantly increased the phosphorylation of MARCKS when compared with synaptic activity by itself (ES) (Figure 7A), indicating that synaptic activity with muscle contraction has a higher effect on the MARCKS phosphorylation than presynaptic activity by itself. 

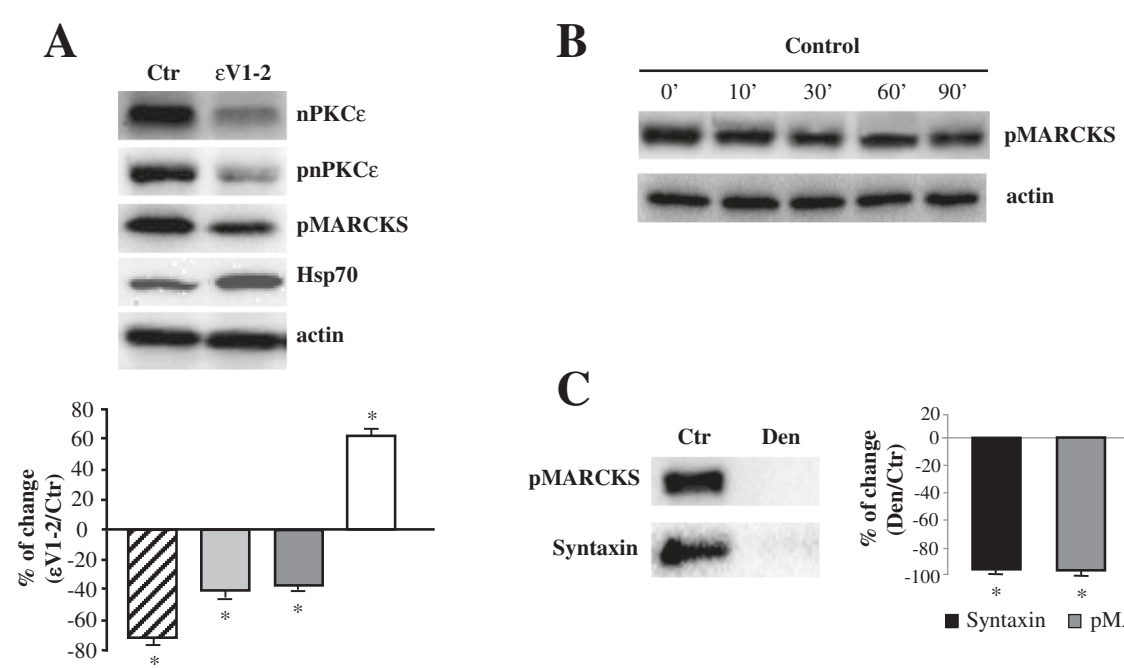

$$
\begin{aligned}
& \square^{\text {nPKCe }} \square \text { pMARCKS } \\
& \square \text { pnPKCe } \square \text { Hsp70 }
\end{aligned}
$$

Figure $5 \mathrm{nPKC} \varepsilon$ regulates phosphorylation of MARCKS in skeletal muscle. (A) shows the Western blotting analysis of $\mathrm{nPKC} \varepsilon$, $\mathrm{pnPKC} \varepsilon$, pMARCKS and Hsp70 in control adult muscles (Ctr) and after incubation with peptide $\varepsilon V 1-2$ (10 min). (B) shows the time course of the level of pMARCKS in adult diaphragm muscle in resting conditions after muscle dissection. (C) shows the Western blotting analysis of pMARCKS and syntaxin in denervated EDL muscle. The quantitative histograms in A and C show the percentage of changes respect to the control and normalized with actin. The data are mean \pm SD values from at least 5 independent experiments. ${ }^{*} p<0.05$. Experiments were performed using diaphragm muscle.

Because electrical activity-induced muscle contraction promotes changes in $\mathrm{nPKC} \varepsilon$ through TrkB activity, next, we plan to know whether muscle contraction could affect MARCKS phosphorylation through TrkB activity. Thus, we analyzed the amount of pMARCKS in contracting muscles in which has been selectively inhibited TrkB activity using the anti-TrkB antibody (47/TrkB) or the fusion protein trkB-Fc (to chelate endogenous BDNF/NT-4). We found that TrkB blockade resulted in a significant decrease in pMARCKS (Figure 7B). We obtained the same result with the two blockade methods. These results demonstrate that electrical activity-induced muscle contraction promotes changes in pMARCKS through TrkB activity.

In summary, the data in this section indicates that $\mathrm{nPKC} \varepsilon$ regulates phosphorylation of MARCKS in NMJ nerve terminal and that presynaptic activity enhances nPKCE-dependent MARCKS phosphorylation. Moreover, the synaptic activity-induced muscle contraction further enhances MARCKS phosphorylation through TrkB signaling.

\section{PMA-induced PKC-coupling to ACh release potentiation involves $\mathrm{nPKC} \varepsilon$}

It is currently believed that PKCs can be strongly activated by such phorbol esters as phorbol 12-myristate 13-acetate (PMA), which potentiates ACh release. Therefore, although it has been reported that PMA has targets other than PKC for regulating neurotransmission [34,35], it should be determined whether the $\mathrm{nPKC} \varepsilon$ plays a role in PMAinduced ACh release.
The histogram in Figure 8A shows that evoked ACh release can be strongly increased by incubation of the diaphragm muscle with PMA (raw data in Figure 8B left; see also $[5,28,36])$. Blocking the $\mathrm{nPKC} \varepsilon$ isoform at low concentrations of the peptide $\varepsilon \mathrm{V} 1-2(1$ and $10 \mu \mathrm{M})$ significantly reduces the effect of PMA $(\sim 60 \%$; raw data in Figure $8 \mathrm{~B}$ right) whereas at high concentrations of $\varepsilon V 1-2$ $(100 \mu \mathrm{M})$ PMA no longer potentiates ACh release. Data in Figure 8A are quantal content (the quantal content M- was estimated with the direct method by recording mEPPs and EPPs simultaneously and then calculating the ratio: $\mathrm{M}=$ Average Peak EPP/Average Peak mEPP) and therefore reflects a presynaptic effect of $\varepsilon V 1-2$ on PMA-induced ACh release potentiation. To further discard any postsynaptic contribution we measured the average amplitude of the mEPPs after incubation with $\varepsilon V 1-2(1-100 \mu \mathrm{M})$ and PMA together or separately and found no difference above a non-significant $9 \%(\mathrm{P}>0.05)$ as compared with the non-incubated control. We conclude that $\mathrm{nPKC} \varepsilon$ was activated by PMA and then coupled to potentiate release. Inhibition with the peptide $\varepsilon V 1-2$ eliminates the contribution of the epsilon isoform and, therefore, the PMA-induced PKC-coupling to ACh release potentiation significantly involves $\mathrm{nPKC} \varepsilon$ activation.

These results suggest that $\mathrm{nPKC} \varepsilon$ is involved in controlling transmitter release at the NMJ. It remains to further determine the specific mechanism of its contribution. However, bearing in mind all the results, we conclude that the $\mathrm{nPKC}$ isoform is exclusively located in the 


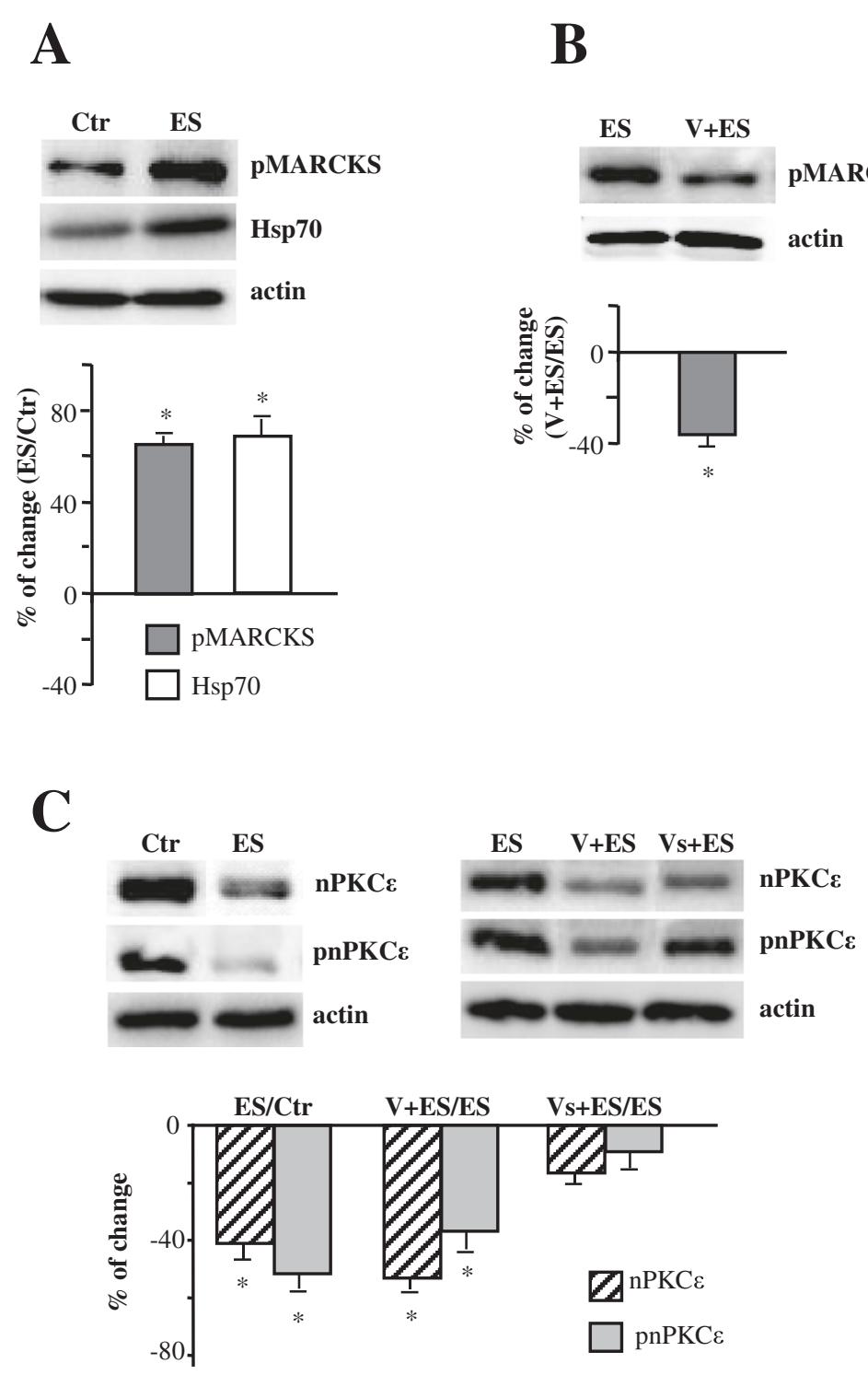

Figure $6 \mathrm{nPKC} \varepsilon$ regulates phosphorylation of MARCKS in adult skeletal muscle, in an activity-dependent way. (A) shows the Western blotting analysis of pMARCKS and Hsp70 in control (Ctr) and in stimulated muscles (ES). (B) shows the effects of $\varepsilon \mathrm{V} 1-2$ incubation and electrical activity $(V+E S)$ on the amount of pMARCKS. (C) shows the Western blotting analysis of $n P K C \varepsilon$ and pnPKC $\varepsilon$ in several conditions of stimulation: in control (Ctr), in stimulated muscles (ES), in stimulated muscles previously incubated with the blocking peptide $(V+E S)$, in stimulated muscles previously incubated with the inactive peptide $(V s+E S)$. In all these experiments, the phrenic nerve was stimulated at $1 \mathrm{~Hz}$ for a 30-minute period and muscle contraction was prevented. The data are means \pm SD values from at least 5 independent experiments and are normalized with actin. ${ }^{*} p<0.05$. Experiments were performed using diaphragm muscle.

presynaptic component of the NMJs and it is involved in the PMA-induced transmitter release mechanism at the NMJ. Moreover, synaptic activity-induced muscle contraction enhances $\mathrm{nPKC} \varepsilon$, and its catalytic function to increase phosphorylation of MARCKS, through TrkB activity.

\section{Discussion}

Recent studies provide evidence that $\mathrm{nPKC} \varepsilon$ could regulate distinct aspects of neural functions, including neurotransmitter release and signal transduction [10,37]. Here, we have examined the presence of the nPKC $\varepsilon$ in the adult NMJ, its synaptic activity-related expression, its regulation by muscle contraction and its involvement in ACh release.

$\mathrm{nPKC} \varepsilon$ expression and localization at the NMJ

It has been shown by Western blot analysis that $\mathrm{nPKC} \varepsilon$ is widely distributed in the central nervous system [10] and skeletal muscle $[11,12]$. There is also a predominant presence of $n \mathrm{PKC} \varepsilon$ mRNA in the brain $[38,39]$. Substantial amounts of $\mathrm{nPKC} \varepsilon$ protein have been also detected 

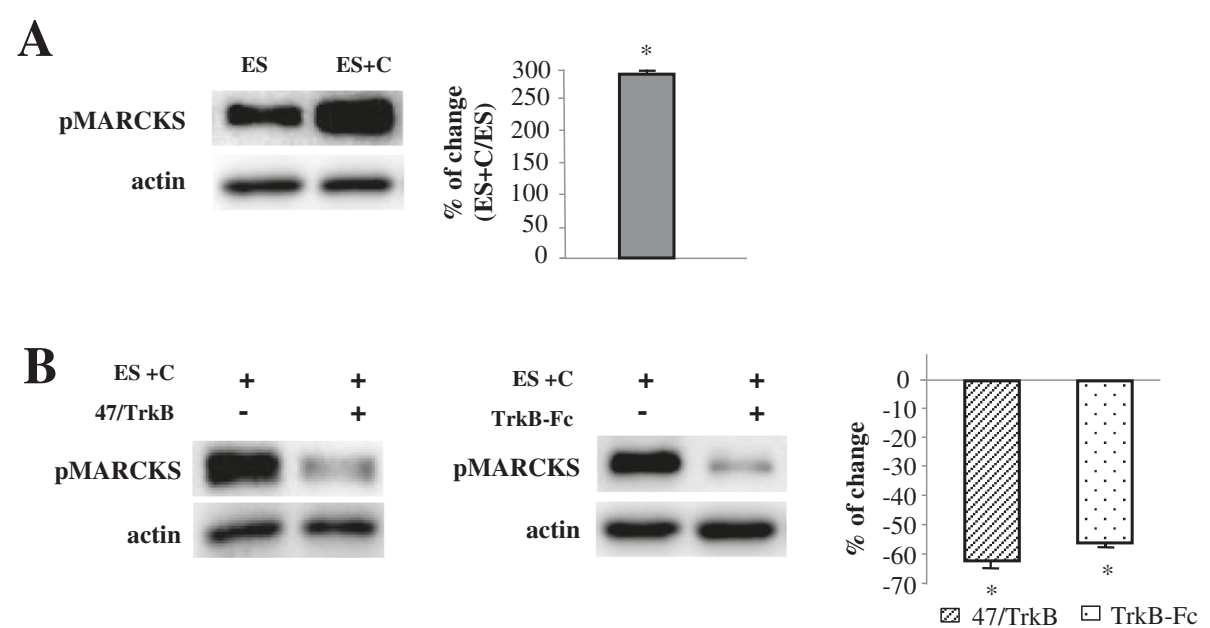

Figure 7 Muscle contraction enhances phosphorylation of MARCKS through TrkB. (A) shows the Western blotting analysis of pMARCKS in synaptic membrane in adult stimulated muscles with (ES $+C$ ) and without (ES) muscle contraction. (B) shows the Western blot analysis of pMARCKS immunoreactivity levels in adult contracting muscles $(E S+C)$ in which has been selectively inhibited TrkB activity using the anti-TrkB antibody (47/TrkB) or the fusion protein trkB-Fc (to chelate endogenous BDNF/NT-4). In all these experiments, the phrenic nerve was stimulated at $1 \mathrm{~Hz}$ for a 30-minute period and muscle contraction was prevented (ES) or not $(E S+C)$. The data are means \pm SD values from at least 5 independent experiments and are normalized with actin. ${ }^{*} p<0.05$. Experiments were performed using diaphragm muscle.

in the rat brain, even at birth but a considerable increase was observed 1-2 weeks postnatal, which suggests that $\mathrm{nPKC} \varepsilon$ is involved in constructing neural networks because it coincides with synapse formation [10]. Likewise, we found that substantial amounts of $\mathrm{nPKC} \varepsilon$ were expressed in the rodent skeletal muscle being more abundant during the development than in the adult (roughly twice).

nPKC $\varepsilon$ and its phosphorylated form are located in the membrane fraction of the synapse-containing zone of the adult skeletal muscle. Furthermore (in correspondence with the denervation experiments), we localized $\mathrm{nPKC} \varepsilon$ in the motor nerve terminals at the adult NMJ but not in the Schwann and postsynaptic muscle cells. Immunohistochemistry performed in the central nervous system reveals that the enzyme is most abundantly expressed in the hippocampus [10,40]. Interestingly, the immunoreactivity of the protein is evident in the nerve fibers and precise observation using electron microscopy reveals its presynaptic localization $[6,40]$ as we found in the NMJ. These findings strongly indicate that $\mathrm{nPKC} \varepsilon$ may be involved in presynaptic functions such as neurotransmitter release in mature synapses.

\section{Synaptic activity, nPKC $\varepsilon$ and pMARCKS}

Because the synaptic function of PKC family is regulated by activity [25], we investigated whether synaptic activity regulates the translocation to the synaptic membrane of $\mathrm{nPKC} \varepsilon$ and its phosphorylated form (which is an indication of its activation). Furthermore, because it has been reported that electrical stimulation-induced contraction increases the translocation of PKC to the membrane [25,41-43], we also wanted to study separately the effect on $\mathrm{nPKC} \varepsilon$ of the presynaptic stimulation and synaptic transmission from the possible effect of the muscle cell contraction. Our results suggest that $\mathrm{nPKC} \varepsilon$ has a role in some activity-related mechanism at the NMJ, and that muscle activity has an important impact on it. We found that electrical stimulation of synaptic inputs to the skeletal muscle and the resulting muscle contraction significantly increased the amount of $\mathrm{nPKC} \varepsilon$ and its phosphorylated form in the synaptic membrane (Figure 3A). When the contraction was inhibited by cutting the muscle fibers [26-28] or by using $\mu$-CgTx-GIIIB $[28,29]$, electrical stimulation resulted in a significant decrease of $\mathrm{nPKC} \varepsilon$ in the membrane (Figure 3). These results clearly indicate that muscle contraction induces an important signaling that reverses the effect of nerve stimulation by itself on $\mathrm{nPKC} \varepsilon$ level in the synaptic membrane, suggesting that contraction is a necessary condition for the $\mathrm{nPKC} \varepsilon$ catalytic function. A similar action of the muscle contraction related to cPKC isoforms has been previously described [25].

What could be the physiological significance of $\mathrm{nPKC} \varepsilon$ levels being downregulated functionally by ES and, at the same time, being up-regulated by muscle contraction? The analysis of the substrate phosphorylation by nPKC $\varepsilon$ could help. Because there are no known nPKCespecific substrates, we used MARCKS for several reasons. MARCKS is a widely distributed actin cross-linking protein that is highly phosphorylated on serine residues after PKC activation [13-15]. The phosphorylation of MARCKS has been used to assess both the activation and inhibition 


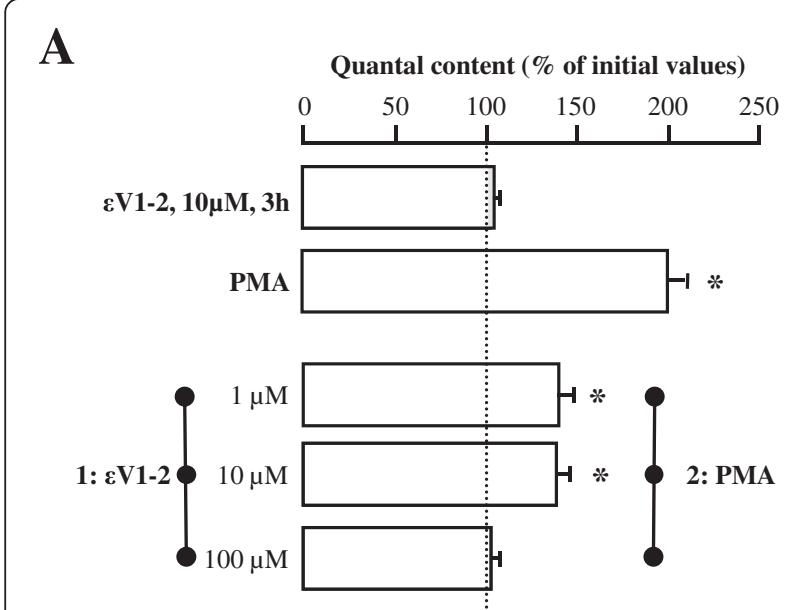

\section{B}

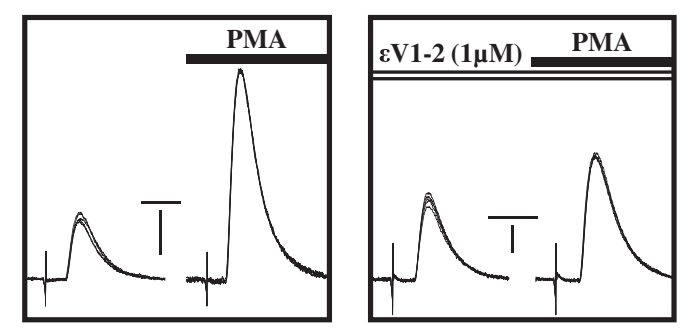

Figure 8 PMA-induced PKC-coupling to ACh release potentiation involves $\mathbf{n P K C} \boldsymbol{\varepsilon}$. The histogram in (A) indicates that ACh release is increased by incubation with PMA. The dose-dependence analysis of the effect of the $\varepsilon V 1-2$ shows that the previous block of the $\mathrm{nPKC} \varepsilon$ reduces $(1$ and $10 \mu \mathrm{M})$ and even abolishes $(100 \mu \mathrm{M})$ the PMA potentiation of ACh release. For each kind of experiment: $n=5$ adult muscles and a minimum of 15 fibers per muscle. *means $p<0.05$. (B) shows the raw data of superimposed EPPs in the conditions described. Thus, the integrity of $n P K C \varepsilon$ seems a necessary condition if the PMA-induced transmitter release potentiation is to be fully expressed. Vertical bars: left, $10 \mathrm{mV}$; right, $5 \mathrm{mV}$. Horizontal bars: $4 \mathrm{~ms}$. Experiments were performed using diaphragm muscle.

of PKC function [44]. MARCKS seems to be a key participant in actin cytoskeleton remodeling, which is the instrument to promote transfer of synaptic vesicles to the plasma membrane, relating thus MARCKS to neurotransmitter release [17]. In addition, $\mathrm{nPKC} \varepsilon$ regulates large dense-core vesicle release via phosphorylation of MARCKS [16]. Our results show that MARCKS phosphorylation is dependent on $\mathrm{nPKC} \varepsilon$ at the $\mathrm{NMJ}$ and its phosphorylation depends on the synaptic activity (with and without muscle contraction). Thus, the increase in the amount of the nPKCe and pnPKCe in the synaptic membrane after muscle contraction is in concordance with the increased phosphorylation of the PKC substrate MARCKS (Figure 7A). However, the results also show that $\mathrm{nPKC} \varepsilon$ dependentphosphorylation of MARCKS occurs when there is not muscle contraction (Figure 6A-B), indicating that presynaptic activity by itself is enough to induce some increase in pMARCKS. Nevertheless, pMARCKS is much higher in contracting muscles than in stimulated muscles without contraction (Figure 7A). Thus, it seems that the amount of pMARCKS depends on the amount of nPKCe active (which is higher when muscle contraction occurs) and, therefore, muscle contraction is necessary as a mechanism to increase the $\mathrm{nPKC} \varepsilon$ level in the synaptic membrane. Interestingly, when $\mathrm{nPKC} \varepsilon$ translocation is inhibited by $\varepsilon V 1-2$ in nerve-stimulated muscles, both nPKCe (Figure 6C) and pMARCKS (Figure 6B) significantly decrease indicating not only, as indicated above, that synaptic activity-induced phosphorylation of MARCKS depends on catalytic function of nPKC but also that activity-dependent $\mathrm{nPKC} \varepsilon$ activation could results in its sustained work (may be to regulate phosphorylation of MARCKS) and subsequently in its detachment from the membrane that eventually could result in degradation or downregulation of the enzyme. In these conditions, Hsp70 (a heat shock protein which has a role in prolonging the lifetime of activated PKC) significantly increases (Figure 6A) suggesting a major interaction of Hsp70 with pnPKCe, which could prolong the lifetime of active ${ }^{n P K C} \varepsilon(\mathrm{pnPKC} \varepsilon)$ and sustain its function to promote phosphorylation of MARCKS. Together, these results indicated that synaptic activity by itself could activate $\mathrm{nPKC} \varepsilon$ to enhance MARCKS phosphorylation at the NMJ and that muscle contraction could be necessary as a mechanism to increase the pnPKCE and pMARCKS levels. It has been described in other synapses and systems a link between phosphorylation of MARCKS and $\mathrm{nPKC} \varepsilon$ $[16,45,46]$. However, because MARCKS can be phosphorylated by other PKCs we cannot fully discount that isoforms other than $\mathrm{nPKC} \varepsilon$ phosphorylate this PKCsubstrate in response to the increased activity, and related to the $\mathrm{nPKC} \varepsilon$ activity, or even that other kinases are involved $[47,48]$.

On the other hand, the blockade, in not stimulated muscles, of the translocation of $\mathrm{nPKC} \varepsilon$ (and therefore its phosphorylating activity) with the $\varepsilon \mathrm{V} 1-2$ peptide, decreased the level of $\mathrm{nPKC} \varepsilon$ and $\mathrm{pnPKC} \varepsilon$ (see Figure 5A). We interpret this result as the $\mathrm{nPKC} \varepsilon$ activity inhibition as a result of the incubation with the specific translocation inhibitor peptide. This can be confirmed because the decrease in $\mathrm{nPKC} \varepsilon$ is accompanied by a parallel decrease in pMARCKS (Figure 5A), which indicates not only that this isoform plays a role in phosphorylating MARCKS but also that the inhibitor peptide acts on the epsilon isoform.

\section{Effect of synaptic activity-induced contraction on nPKC $\varepsilon$ through TrkB activity}

How is $\mathrm{nPKC} \varepsilon$ level increased when muscle contraction is not prevented? Recently, several evidence support muscle activity-dependent BDNF and TrkB signaling as a key regulator of neuromuscular function. First, BDNF 
has been identified as a contraction-inducible protein in human skeletal muscle [49]. Secondly, basal levels of neuromuscular activity are required to maintain normal levels of BDNF in the neuromuscular system [50]. Finally, BDNF and TrkB contribute to the neuromuscular junction transmission [32,51]. Accordingly, we aimed to investigate whether nerve induced-muscle activity would produce a neurotrophin inducing a signaling pathway through TrkB to affect presynaptic nPKC $\varepsilon$ and its catalytic activity. Our results show that blockade of TrkB prevents muscle contraction-induced $\mathrm{nPKC} \varepsilon$ increase (Figure 4A-B) and phosphorylation of MARCKS (Figure 7B) indicating that a neurotrophin acts through TrkB to increase $\mathrm{nPKC} \varepsilon$ and pMARCKS on the nerve terminal. Moreover, we found that phosphorylation of $\mathrm{nPKC} \varepsilon$ increases significantly when stimulated muscles were incubated with BDNF exogenous, indicating that BDNF could be the neurothrophin that activates TrkB to enhance $\mathrm{nPKC} \varepsilon$ action and pMARCKS on the nerve terminal. It could be speculated that TrkB works to regulate $\mathrm{nPKC} \varepsilon$ (and pnPKCe) by phosphorylating PLCY (phosphoinositide-specific phospholipase $\mathrm{C} \gamma$ ). Phosphorylation of TrkB on Tyr785 recruits PLCy to the receptors, and the enzyme becomes activated upon tyrosine phosphorylation [52,53]. Activated PLCY hydrolyses PI $(4,5) \mathrm{P}_{2}$ (phosphatidylinositol 4,5-biphosphate) to generate inositol tris-phosphate $\left(\mathrm{IP}_{3}\right)$ and DAG, which activates $\mathrm{nPKC} \varepsilon$ (once the isoform has been previously phosphorylated by PDK (3-phosphoinositide dependent protein kinase) and autophosphorylated [54-56]. These findings provide mechanistic insight into how synaptic activity induced-muscle contraction could regulate the presynaptic action of the $\mathrm{nPKC} \varepsilon$ and suggest that muscle contraction is an important regulatory step in TrkB signaling at the NMJ.

\section{Effect of $n P K C \varepsilon$ on PMA-induced PKC-coupling to ACh release potentiation}

One aim of the present study is to determine whether $\mathrm{nPKC} \varepsilon$ is involved in the neurotransmission mechanism. Although it has been reported that PMA has targets other than PKC for affecting neurotransmission (Munc13) [34,35], PMA strongly activates PKC family to enhance neurotransmission [5,36,57-60]. Here, we show that blocking the $\mathrm{nPKC} \varepsilon$ with $\varepsilon \mathrm{V} 1-2$ fully inhibited (Figure 8) the PMA-induced pharmacologic potentiation of ACh release in a concentration-dependent way indicating that $\mathrm{nPKC} \varepsilon$ plays a role in neurotransmission at the NMJ. Therefore, $\mathrm{nPKC} \varepsilon$ has a key role regulating the ACh release by itself or by modulating the action of other PKCs isoforms. It has been demonstrated that PKC family is involved in the modulation of ACh release at the NMJ [60]. Moreover, exogenously added BDNF potentiates evoked ACh release in a TrkB receptor dependent manner [32]. Furthermore, the TrkB signaling needs an operative PKC pathway to couple to the release mechanism and potentiate it [61]. nPKCE could be related with this PKC-TrkB mechanism that modulates ACh release at the NMJ. Future experiments will be necessary to determine how $\mathrm{nPKC} \varepsilon$ is critical to the maintenance of transmitter release and to better understand how muscle contraction-induced phosphorylation of MARCKS, regulated by $\mathrm{nPKC}$, is involved in neuromuscular transmission. Furthermore, $\mathrm{nPKC} \varepsilon$ may work in parallel with the active zone positioning and priming protein Munc13 to enhance neurotransmission because recent studies proposed two probably converging pathways stimulated by phorbol esters (and DAG) to induce potentiation (PKC- and Munc13-dependent) $[62,63]$. It has been proposed that a PKC/Munc18-1 dependentredistribution of synaptic vesicles after phorbol ester stimulation (via PKC phosphorylation of the SNARE/SM fusion protein Munc18-1), may be the morphological correlate of the increased release efficiency during potentiation [62]. In this redistribution, MARCKS may be involved because their role in actin cytoskeleton remodeling, which is the instrument to promote transfer of synaptic vesicles to the plasma membrane.

In physiological conditions, nerve action is linked to muscle contractions, therefore it is important to provide a mechanism linking muscle contraction to nerve function. Figure 9 shows a diagram illustrating how synaptic activity-induced muscle contraction could regulate the presynaptic action of the $\mathrm{nPKC} \varepsilon$ through TrkB signaling to enhance phosphorylation of MARCKS that could be related to the neurotransmitter release.

\section{Conclusion}

In summary, our results indicate that $\mathrm{nPKC} \varepsilon$ is exclusively located in the presynaptic component of the NMJs, is regulated by synaptic activity involving muscle contraction through TrkB function to enhance phosphorylation of MARCKS and finally, $\mathrm{nPKC} \varepsilon$ is involved in ACh release.

\section{Material and methods}

\section{Animals}

Diaphragm and levator auris longus (LAL) muscles of young adult and postnatal male Sprague-Dawley rats (3040 and 6 days; Criffa, Barcelona, Spain) were used to perform stimulation experiments, immunohistochemistry and electrophysiological experiments. Denervation experiments were performed in the extensor digitorum longus muscle (EDL). The animals were cared for in accordance with the guidelines of the European Community Council Directive for the humane treatment of laboratory animals.

\section{Materials \\ Antibodies}

Primary antibodies used for Western blot and immunohistochemistry analysis were obtained from different 
sources, as follows: rabbit anti-PKCe, goat anti-phospho$\mathrm{PKC \varepsilon}$ (Ser729) and rabbit anti-PKC $\alpha$ polyclonal antibodies were purchased from Santa Cruz Biotechnology (Santa Cruz, CA); rabbit anti-PKCe and rabbit antiphospho-PKCe (Ser729) polyclonal antibodies were obtained from Upstate Biotechnology (Millipore, Lake Place $\mathrm{NY}$ ); mouse anti-PKC $\alpha$ monoclonal antibody was purchased from BD Transduction Laboratories (Lexington, KY); rabbit anti-phospho-MARCKS (myristoylated alaninerich C kinase substrate) (S152/S156) polyclonal antibody from R\&D systems (Biotecnology, Minneapolis); rabbit anti-HSP70/HSP72 polyclonal antibody from Enzo (Life Sciences, Inc.); goat anti-GAPDH from Imgenex (San Diego, CA) and rabbit anti-pan-actin polyclonal antibody from Cell Signaling Technology, Inc (Beverly, MA). The secondary antibodies used in the Western blot were goat anti-mouse and donkey anti-rabbit conjugated to HRP (Horseradish Peroxidase) from Jackson Immunoresearch and rabbit anti-goat HRP from Molecular Probes (Eugene, OR). For the immunohistochemistry we also used antibodies that are commonly used as markers to differentially detect the parts of the NMJ (syntaxin, neurofilament-200 and S100): the mouse monoclonal antibody and the rabbit polyclonal anti-syntaxin antibody (Sigma, St Louis, MO); the monoclonal and polyclonal anti-neurofilament-200 antibodies (Sigma, St Louis, MO); the rabbit anti-S100 antibody (Dako, Carpinteria, CA) and the mouse anti-S100 antibody (Acris, Germany). The secondary antibodies used were donkey anti-rabbit or anti-mouse conjugated to Alexa Fluor 488 and Alexa Fluor 647 from Molecular Probes (Eugene, OR). Postsynaptic acetylcholine receptors (AChRs) were detected with $\alpha$-bungarotoxin $(\alpha$-BTX) conjugated to tetramethyl rhodamine iso-thiocyanate (TRITC) from Molecular Probes (Eugene, OR).

As a control, the primary antibodies were omitted from some muscles during the immunohistochemical and Western blot procedures. These control muscles never exhibited positive staining or revealed bands of the appropriate molecular weight with the respective procedures. In double-staining protocols, omitting either one of the two primary antibodies completely abolished the corresponding staining and there was no cross-reaction with the other primary antibody. Pretreatment of a primary antibody with an excess of the appropriate blocking peptide (between three- and eightfold by weight) in skeletal muscle tissue prevented immunolabeling. All the primary antibodies used detect a single band with the referenced molecular weight on Western blot (manufacturer's data sheets; see also Figure 1 for $\mathrm{nPKC} \varepsilon$ and $\mathrm{pnPKC} \varepsilon$ skeletal muscle).

\section{Reagents}

For the different treatments we used substances that modulate PKC activity: Phorbol 12-myristate 13-acetate (PMA, Sigma) was made up as $10 \mathrm{mM}$ stock solution in

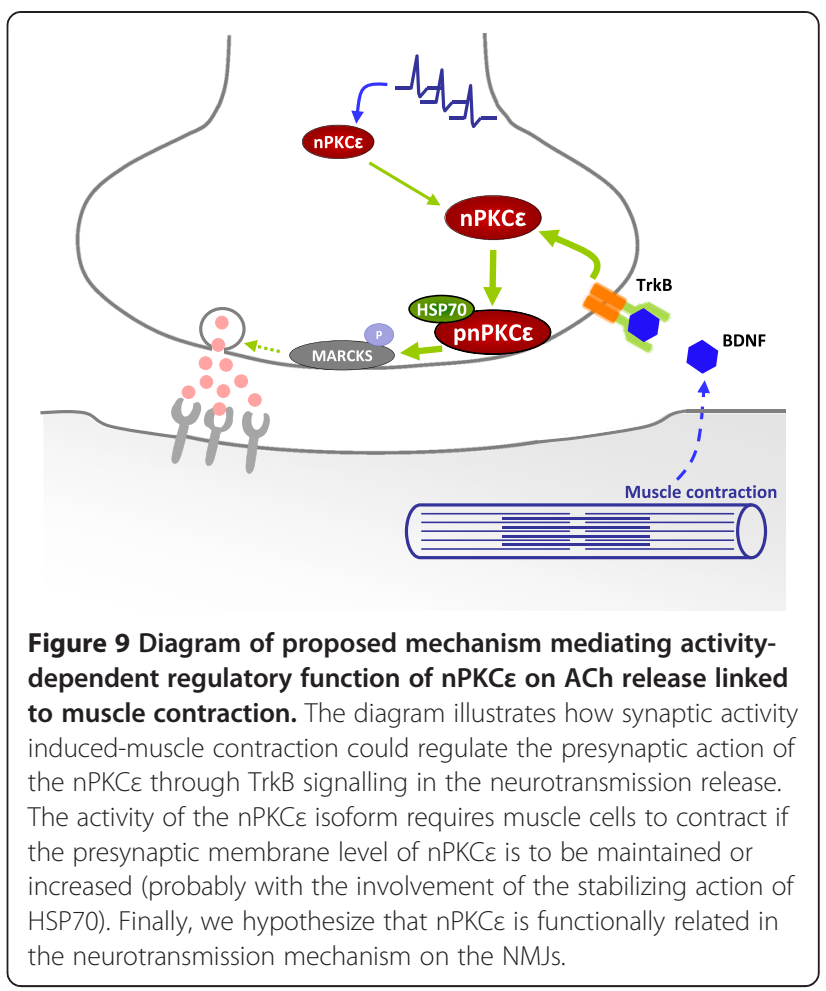

dimethylsulfoxide (DMSO; Tocris, Ellisville, MO, USA). The working solution was PMA $10 \mathrm{nM} . \varepsilon \mathrm{V} 1-2$, nPKC $\varepsilon$ specific translocation inhibitor peptide (myristoylated PKC- $\varepsilon$ V1-2 peptide, EAVSLKPT) from Calbiochem (Merk, Germany) was made up as $1 \mathrm{mM}$ in distilled water or normal Ringer solution. Working solutions were 1, 10 and $100 \mu \mathrm{M}$. As a negative control of the nPKC $\varepsilon$-specific translocation inhibitor peptide we used scrambled $\varepsilon V 1-2$ peptide ( $\varepsilon V 1-2-s$, LSETKPAV), containing the same aminoacids as the inhibitor peptide but in a different sequence, from Calbiochem (Merk, Germany). Working solutions were 1,10 and $100 \mu \mathrm{M}$.

\section{TrkB receptor-inhibitors}

The TrkB ligand N2-(2-\{[(2-oxoazepan-3-yl)amino $]$ carbonyl\}phenyl)benzo[b]thiophene-2-carboxamide (ANA12; cat. no. BTB06525; MW $407.5 \mathrm{~g} / \mathrm{mol}$ ) was purchased from Maybridge (Cornwall, UK) and was made up as a $10 \mathrm{mM}$ in DMSO. Anti-TrkB (clone 47/TrkB; cat. no. 610102; $250 \mu \mathrm{g} / \mathrm{ml}$ ) was obtained from BD Transduction Laboratories (Lexington, KY). Recombinant human trkB/ Fc Chimera (trkB-Fc; 688-TK from R\&D Systems, Minneapolis), $100 \mu \mathrm{g} / \mathrm{ml}$. Working solutions: ANA-12, $10 \mu \mathrm{M}$; anti-TrkB, $10 \mu \mathrm{g} / \mathrm{ml}$; trkB-Fc, $1-5 \mu \mathrm{g} / \mathrm{ml}$.

\section{Stimulation of the muscle and incubations with $\varepsilon \mathrm{V}_{1-2}$ peptide and PMA}

In all the experimental protocols, the diaphragm muscle from young adult rats were excised together with the 
phrenic nerve and placed in oxygenated Ringer solution (see below) continuously bubbled with $95 \% \mathrm{O} 2 / 5 \% \mathrm{CO}_{2}$ at room temperature. To stimulate the muscle, the phrenic nerve was stimulated at $1 \mathrm{~Hz}$ for a 10 - or 30 minute period by an A-M Systems 2100 isolated pulse generator (A-M System, Carlsborg, WA). To study separately the effect of the presynaptic stimulation (and synaptic transmission) from the effect of the muscle cell contraction, we performed experiments in which contractions were prevented $(E S)$ or not $(E S+C)$. The muscle was prevented from contracting by cutting on either side of the main intramuscular nerve branch (see below). We also performed experiments to discard any possible artifact due to the muscle fiber cutting. Cut muscles were compared with muscles where muscle contraction was abolished by using $\mu$-conotoxin GIIIB ( $\mu$-CgTx-GIIIB, $3 \mu \mathrm{M}-1.5 \mu \mathrm{M}$, from ICS, International Clinical Service $\mathrm{GmbH}$, München). The two methods used to prevent muscle contraction did not show differences with regard to electrophysiological parameters of the neurotransmission (see also later in Results).

We used a nonpharmacological tool to inhibit specifically $\mathrm{nPKC} \varepsilon$ isoform. We used the $\mathrm{nPKC} \varepsilon$-specific translocation inhibitor peptide, epsilonV1-2 ( $\varepsilon V 1-2$; [20]), to block the isoform activity so that we could analyze its possible constitutive involvement in cell functions in the resting and stimulated NMJs. This peptide interferes in the $\mathrm{nPKC \varepsilon}$ interaction with the anchoring protein epsilon-RACK and, therefore, inhibits the anchoring of nPKCe near its substrates (and translocation to the membrane of the active isoform) and prevents any subsequent substrate phosphorylation and activity [64]. For $\mathrm{nPKC}$, the PKC-RACK interaction occurs via a C2-like domain that does not bind $\mathrm{Ca}^{2+}[64,65]$. Thus, the classic calcium-dependent cPKCs are not inhibited with the peptide $\varepsilon \mathrm{V} 1-2$ because they do not possess this $\mathrm{C} 2$-like region. In addition, studies using peptide translocation inhibitors of $\mathrm{nPKC} \varepsilon(\varepsilon \mathrm{V} 1-2)$ and $\mathrm{nPKC} \delta(\delta \mathrm{V} 1)$ demonstrated that these isoforms (nPKCe and $\mathrm{nPKC} \delta$ ) can have opposing actions within a given cell type (cardiomyocyte) [66-68] and also showed the isoform specificity of the peptides. There are several evidence that show that the effects found using the nPKCE-specific translocation inhibitor peptide can be confirmed when $\mathrm{nPKC} \varepsilon$ knockout mice are used [69,70]. The effect of $\varepsilon V 1-2$ $(100 \mu \mathrm{M})$ was studied in parallel to the effect of the scrambled version of this peptide $(\varepsilon V 1-2-s, 100 \mu \mathrm{M})$. In some experiments, stimulated muscles were previously incubated with the peptide $\varepsilon V 1-2$ or with its inactive form (30 minutes).

To activate PKC family with PMA, a potent but nonselective-isoform PKC activator, the diaphragm muscles were incubated for 10, 30 or 60 minutes on a Sylgardcoated Petri dish containing Ringer solution for the control muscles, or $\varepsilon \mathrm{V} 1-2(100 \mu \mathrm{M})$, scrambled $\varepsilon \mathrm{V} 1-2$ $(100 \mu \mathrm{M})$ or PMA $(10 \mathrm{nM})$.

\section{Western blot analysis}

Diaphragm muscles from newborn and adult rat were dissected, frozen in liquid nitrogen, and stored at $-80^{\circ} \mathrm{C}$ before use. The muscles were homogenized using a high-speed homogenizer (overhead stirrer, VWR International, Clarksburg, MD) in lysis buffer containing $150 \mathrm{mM} \mathrm{NaCl}, 20 \mathrm{mM}$ Tris-HCl, pH 7.5, 2 mM EGTA, and $5 \mathrm{mM}$ EDTA supplemented with $1 \%$ Triton X-100, $1 \mathrm{mM}$ PMSF, $50 \mathrm{mM} \mathrm{NaF}$, and $1 \mathrm{mM}$ sodium orthovanadate from Sigma, (St. Louis, MO) and protease inhibitor cocktail (Sigma-Aldrich Corp., Saint Louis, MO, USA). Insoluble material was removed by centrifugation at $1000 \mathrm{~g}$ for 10 minutes. The supernatants were collected and centrifuged at $15000 \mathrm{~g}$ for 20 minutes. Finally, the resulting supernatants (total protein lysates) were collected. Protein concentrations were determined by using the Bio-Rad DC protein assay (Bio-Rad, Hercules, CA). Experimental procedures were performed to determine the linear and quantitative dynamic range for each target protein and the appropriate dilutions of samples were used for accurate and normalized quantitation by means of densitometric analysis. Protein samples of 15 or $30 \mu \mathrm{g}$ were separated by $8 \%$ SDS-polyacrylamide electrophoresis and electrotransferred to PVDF membranes (Hybond $^{\mathrm{Tm}}-\mathrm{P}$; Amersham, GE Healthcare). The membranes were blocked in Tris-buffered saline-0.1\% Tween-20 (TBS-T) containing $5 \%(\mathrm{~W} / \mathrm{V})$ nonfat dry milk or in a blocking reagent to preserve phosphoprotein antigens (PhosphoBLOCKER ${ }^{\mathrm{m}}$; Cell Biolabs, Inc.) and probed with the primary antibody overnight at $4{ }^{\circ} \mathrm{C}$. The membranes were then incubated with the secondary antibody and visualized enhanced chemiluminescence with the ECL kit (Amersham Life Science, Arlington Heights, IL).

In treated and/or stimulated muscles, the synaptic membranes were obtained. Synaptic and extrasynaptic parts of the diaphragm muscle were separated as previously described [25]. We performed control experiments to check that our protocol for dividing the diaphragm muscle into synaptic and extrasynaptic region was accurate. In some muscles, we repeated the process of separation and detected NMJs with TRITC-conjugated $\alpha$-BTX. We also stained the nerves with an antibody against antineurofilament-200 and did not detect any nerves in extrasynaptic regions. The muscles were homogenized using a high-speed homogenizer (overhead stirrer, VWR International, Clarksburg, MD) in lysis buffer (see above) and the insoluble material was removed in the same way (by centrifugation at $1000 \mathrm{~g}$ for 10 minutes) but now the resulting supernatant was collected and centrifuged at $130000 \mathrm{~g}$ for 1 hour. The supernatant was the cytosolic fraction, and the pellet was the membrane fraction. To 
assess the separation of the membrane fraction from the cytosol, we used a goat antibody directed against Glyceraldehyde 3-phosphate dehydrogenase (GAPDH), a protein specific to the cytosolic fraction. GADPH immunoreactivity was not observed in any case in the membrane fraction. The samples were processed the same way as another sample of total protein (see below).

The blots were visualized with a VersaDoc 3000 (Bio-Rad, Hercules, CA). The densitometry of different bands was analyzed with the MetaMorph software. The integrated optical density of the bands was normalized to the background values and by actin protein. Also, as another loading control we used a total protein analysis (Sypro Ruby protein blot Stain, Bio Rad) to measure the total protein transferred on polyvininylidene difluoride (PVDF) membranes. In all the cases, the quantitative results obtained by using actin or total protein analysis were no different. The relative variations between the bands in the experimental samples and the control samples were calculated in the same image. The data were taken from densitometry measurements made in at least five separate experiments, plotted against controls. Data are mean values \pm SD. Differences between groups were tested using the $t$ Student test or $U$ test (Mann-Whitney), and the normality of the distributions was tested with the KolmogorovSmirnov test. The criterion for statistical significance was $p<0.05$ versus the control.

\section{Immunohistochemistry and confocal microscopy}

Whole muscle mounts were processed by immunohistochemistry to detect the localization of the $\mathrm{nPKC} \varepsilon$ isoform at the NMJ. LAL and diaphragm muscles from young adult rats were fixed with $4 \%$ paraformaldehyde for 30 minutes. After fixation, the muscles were rinsed with PBS and incubated in $0.1 \mathrm{M}$ glycine in PBS. The muscles were permeabilized with $0.5 \%$ Triton X-100 in PBS, and nonspecific binding was blocked with $4 \%$ bovine serum albumin (BSA). Then, muscles were incubated overnight at $4^{\circ} \mathrm{C}$ in mixtures of three primary antibodies raised in different species (anti-nPKCE isoform antibody and anti-syntaxin and anti-neurofilament or syntaxin or anti-S100) and then rinsed. The muscles were then incubated for four hours at room temperature in a mixture of appropriate secondary antibodies. The AChRs were detected with $\alpha$-BTX conjugated with TRITC. At least three muscles were used as negative controls as described above. For a better analysis of the localization of the $\mathrm{nPKC} \varepsilon$ isoform at the NMJ, some muscles were processed to obtain semithin cross-sections from whole-mount multiple-immunofluorescent stained muscles. This method provided a simple and sensitive procedure for analyzing the cellular distribution of molecules at the NMJ [24].

Labeled NMJs from the whole-mount muscles and the semithin cross-sections were viewed with a laser-scanning confocal microscope (Nikon TE2000-E). Special consideration was given to the possible contamination of one channel by another. In experiments involving negative controls, the photomultiplier tube gains and black levels were identical to those used for a labeled preparation made in parallel with the control preparations. At least 25 endplates per muscle were observed, and at least six muscles were studied. Images were assembled using Adobe PhotoShop software (Adobe Systems, San Jose, CA) and neither the contrast nor brightness were modified.

\section{Electrophysiology}

Diaphragm muscles from adult rats were removed surgically and incubated in a Sylgard-Petri dish containing normal Ringer solution (in $\mathrm{mM}$ ) $-\mathrm{NaCl} \mathrm{135,} \mathrm{KCl} 5$, $\mathrm{CaCl}_{2} 2.5, \mathrm{MgSO}_{4} 1, \mathrm{NaH}_{2} \mathrm{PO}_{4} 1, \mathrm{NaHCO}_{3} 15$, glucose 11 - which was bubbled continuously with $95 \% \mathrm{O}_{2}, 5 \%$ $\mathrm{CO}_{2}$. Temperature and humidity were regulated at $26^{\circ} \mathrm{C}$ and $50 \%$, respectively. Spontaneous miniature endplate potentials (MEPPs) and evoked endplate potentials (EPPs) were recorded intracellularly with conventional glass microelectrodes filled with $3 \mathrm{M} \mathrm{KCl}$ (resistance: 20-40 MW). Recording electrodes were connected to an amplifier (Tecktronics, AMS02), and a distant $\mathrm{Ag}-\mathrm{AgCl}$ electrode connected to the bath solution via an agar bridge (agar 3.5\% in $137 \mathrm{mM} \mathrm{NaCl}$ ) was used as a reference. The signals were digitized (DIGIDATA 1322A Interface, Axon Instruments Inc, CA, USA), stored and computer-analyzed. The software Axoscope 9.0 (Axon Instruments Inc, CA, USA) was used for data acquisition and analysis. To prevent muscle contraction during EPP recordings, we used $\mu$-conotoxin GIIIB ( $\mu$-CgTx-GIIIB, $3 \mu \mathrm{M}-1.5 \mu \mathrm{M}$, from ICS, International Clinical Service $\mathrm{GmbH}$, München). After a muscle fiber had been impaled, the phrenic nerve was continuously stimulated (70 stimuli at $0.5 \mathrm{~Hz}$ ) using two platinum electrodes that were coupled to a pulse generator (CIBERTEC CS-20) linked to a stimulus isolation unit. The last 50 EPPs were recorded. We selected fibers with membrane potentials of no less than $-70 \mathrm{mV}$ and used only those results from preparations which did not deviate by more than $5 \mathrm{mV}$ during the recording. The mean amplitude $(\mathrm{mV})$ per fiber was calculated and corrected for non-linear summation (EPPs were usually more than $4 \mathrm{mV}$ ) [71] assuming a membrane potential of $-80 \mathrm{mV}$. Quantal content $(\mathrm{M})$ was estimated by the direct method, which consists of recording mEPPs and EPPs simultaneously and then calculating the ratio: $\mathrm{M}=$ Average Peak EPP/Average Peak mEPP. We studied a minimum of 15 fibers per muscle and usually a minimum of 5 muscles in each type of experiment. The data given in Results are mean values \pm SEM. Only one hemidiaphragm was used from each animal for a given experiment. We used the two-tailed Welch's t-test (for 
unpaired values and variances were not assumed to be equal). Differences were considered significant at $\mathrm{P}<0.05$ $(*)$.

\section{Denervation}

Extensor digitorum longus (EDL) denervation. Young adult rats (30-40 months of age, male) were anesthetized with ketamine/xylazine (K/X; $0.1 \mathrm{ml} / 10 \mathrm{~g}$ body weight intraperitoneal injection of a solution containing $10 \mathrm{mg} / \mathrm{ml} \mathrm{keta-}$ mine and $1 \mathrm{mg} / \mathrm{ml}$ xylazine). To isolate the sciatic nerve, a $0.5 \mathrm{~cm}$ excision was made on the exterior side of the leg at approximately $1 \mathrm{~cm}$ over the level of knee. The excision was made carefully avoiding tissue injury, the sciatic nerve was cut about $1 \mathrm{~mm}$ from the nerve's entrance into the muscle and a $1 \mathrm{~cm}$ segment was excised. The wound was then closed. At the times desired (1-3 days), the rats were anesthetized with pentobarbital and the EDL muscle was excised.

\section{Abbreviations \\ ACh: Acetylcholine; LAL: Levator auris longus muscle; nAChR: Nicotinic acetylcholine receptor; NMJ: Neuromuscular junction; PKC: Protein Kinase C; nPKC $\varepsilon$ : Epsilon PKC; PMA: Phorbol 12-myristate 13-acetate; RACKs: Receptors for activated C-kinase; PS: Phosphatidylserine; DAG: Diacylglycerol: EV1-2: Isozyme-selective translocation inhibitor; $\mathrm{A}-\mathrm{BTX}$ : a-bungarotoxin conjugated TRITC; TrkB: Tyrosine kinase receptor B; BDNF: Brain derived neurotrophic factor; EDL: Extensor digitorum longus muscle; PLCY1: Phosphoinositide-specific phospholipase C $\gamma 1$; PI (4,5) $P_{2}$ : Phosphatidylinositol 4,5-biphosphate; IP ${ }_{3}$ : Inositol tris-phosphate; NT: Nerve terminal; PDK: 3-phosphoinositide dependent protein kinase.}

\section{Competing interests}

The authors declare that they have no competing interests.

\section{Authors' contributions}

TO and NB: data collection, quantitative analysis; literature search, data interpretation, statistics; EH and LN: data collection, quantitative analysis; statistics. MP and MT: data collection; NG and MMS: literature search, data interpretation; MAL and JT: conception and design, literature search, data interpretation, manuscript preparation. JT and MAL contributed equally to this work. All authors read and approved the final manuscript.

\section{Acknowledgements}

This work was supported by a grant from MEC (SAF2011-23711) and a grant from the Catalan Government (Generalitat) (2009SGR01248) (JT). The authors declare no competing financial interests.

Received: 10 November 2014 Accepted: 16 January 2015

Published online: 10 February 2015

\section{References}

1. West JW, Numann R, Murphy BJ, Scheuer T, Catterall WA. A phosphorylation site in the $\mathrm{Na}+$ channel required for modulation by protein kinase $\mathrm{C}$. Science. 1991;254:866-8.

2. Numann R, Hauschka SD, Catterall WA, Scheuer T. Modulation of skeletal muscle sodium channels in a satellite cell line by protein kinase C. J Neurosci. 1994; 14:4226-36.

3. Byrne $\mathrm{JH}$, Kandel ER. Presynaptic facilitation revisited: state and time dependence. J Neurosci. 1996;16:425-35.

4. Catterall WA. Interactions of presynaptic Ca2+ channels and snare proteins in neurotransmitter release. Ann N Y Acad Sci. 1999;868:144-59.

5. Santafé MM, Lanuza MA, Garcia N, Tomàs J. Calcium inflow-dependent protein kinase $\mathrm{C}$ activity is involved in the modulation of transmitter release in the neuromuscular junction of the adult rat. Synapse. 2005;57:76-84.

6. Tanaka C, Nishizuka Y. The protein kinase C family for neuronal signaling. Annu Rev Neurosci. 1994;17:551-67.
7. Mochly-Rosen D. Localization of protein kinases by anchoring proteins: a theme in signal transduction. Science. 1995;268:247-51.

8. Mochly-Rosen D, Khaner H, Lopez J. Identification of intracellular receptor proteins for activated protein kinase C. Proc Natl Acad Sci U S A. 1991;88:3997-4000.

9. Mochly-Rosen D, Khaner H, Lopez J, Smith BL. Intracellular receptors for activated protein kinase $\mathrm{C}$. Identification of a binding site for the enzyme. J Biol Chem. 1991;266:14866-8.

10. Shirai $Y$, Adachi N, Saito N. Protein kinase Cepsilon: function in neurons. FEBS J. 2008;275:3988-94.

11. Moraczewski J, Nowotniak A, Wróbel E, Castagna M, Gautron J, Martelly I. Differential changes in protein kinase $C$ associated with regeneration of rat extensor digitorum longus and soleus muscles. Int J Biochem Cell Biol. 2002;34:938-49.

12. Vary TC, Goodman S, Kilpatrick LE, Lynch CJ. Nutrient regulation of PKCepsilon is mediated by leucine, not insulin, in skeletal muscle. Am J Physiol Endocrinol Metab. 2005;289:E684-94

13. Stumpo DJ, Graff JM, Albert KA, Greengard P, Blackshear PJ. Molecular cloning, characterization, and expression of a cDNA encoding the "80- to 87-kDa" myristoylated alanine-rich C kinase substrate: a major cellular substrate for protein kinase C. Proc Natl Acad Sci U S A. 1989;86:4012-6.

14. Aderem A. The Marcks brothers: a family of protein kinase $C$ substrates. Cell. 1992;71:713-6.

15. Aderem A. Signal transduction and the actin cytoskeleton: the roles of MARCKS and profilin. Trends Biochem Sci. 1992;17:438-43.

16. Park Y-S, Hur E-M, Choi B-H, Kwak E, Jun D-J, Park S-J, et al. Involvement of protein kinase $\mathrm{C}$-epsilon in activity-dependent potentiation of large densecore vesicle exocytosis in chromaffin cells. J Neurosci. 2006;26:8999-9005.

17. Mosevitsky MI. Nerve ending "signal" proteins GAP-43, MARCKS, and BASP1. Int Rev Cytol. 2005;245:245-325.

18. Lu D, Yang H, Lenox RH, Raizada MK. Regulation of angiotensin Il-induced neuromodulation by MARCKS in brain neurons. J Cell Biol. 1998;142:217-27.

19. Rosé SD, Lejen T, Zhang L, Trifaró JM. Chromaffin cell F-actin disassembly and potentiation of catecholamine release in response to protein kinase $C$ activation by phorbol esters is mediated through myristoylated alanine-rich C kinase substrate phosphorylation. J Biol Chem. 2001;276:36757-63.

20. Johnson JA, Gray MO, Chen C-H, Mochly-Rosen D. A Protein Kinase C translocation inhibitor as an Isozyme-selective antagonist of cardiac function. J Biol Chem. 1996:271:24962-6.

21. Bornancin F, Parker PJ. Phosphorylation of protein kinase C-alpha on serine 657 controls the accumulation of active enzyme and contributes to its phosphatase-resistant state. J Biol Chem. 1997;272:3544-9.

22. Dutil EM, Toker A, Newton AC. Regulation of conventional protein kinase $C$ isozymes by phosphoinositide-dependent kinase 1 (PDK-1). Curr Biol. 1998:8:1366-75.

23. Hafeez BB, Zhong W, Weichert J, Dreckschmidt NE, Jamal MS, Verma AK. Genetic ablation of PKC epsilon inhibits prostate cancer development and metastasis in transgenic mouse model of prostate adenocarcinoma. Cancer Res. 2011;71:2318-27.

24. Lanuza MA, Besalduch N, Garcia N, Sabaté M, Santafé MM, Tomàs J. Plasticembedded semithin cross-sections as a tool for high-resolution immunofluorescence analysis of the neuromuscular junction molecules: specific cellular location of protease-activated receptor-1. J Neurosci Res. 2007:85:748-56.

25. Besalduch N, Tomàs M, Santafé MM, Garcia N, Tomàs J, Lanuza MA. Synaptic activity-related classical protein kinase $\mathrm{C}$ isoform localization in the adult rat neuromuscular synapse. J Comp Neurol. 2010;518:211-28.

26. Santafé MM, Garcia N, Lanuza MA, Uchitel OD, Tomás J. Calcium channels coupled to neurotransmitter release at dually innervated neuromuscular junctions in the newborn rat. Neuroscience. 2001;102:697-708.

27. Santafé MM, Salon I, Garcia N, Lanuza MA, Uchitel OD, Tomàs J. Muscarinic autoreceptors related with calcium channels in the strong and weak inputs at polyinnervated developing rat neuromuscular junctions. Neuroscience. 2004;123:61-73.

28. Santafé MM, Garcia N, Lanuza MA, Tomàs M, Tomàs J. Interaction between protein kinase $\mathrm{C}$ and protein kinase $\mathrm{A}$ can modulate transmitter release at the rat neuromuscular synapse. J Neurosci Res. 2009;87:683-90.

29. Santafé MM, Lanuza MA, Garcia N, Tomàs M, Tomàs J. Coupling of presynaptic muscarinic autoreceptors to serine kinases in low and high release conditions on the rat motor nerve terminal. Neuroscience. 2007;148:432-40.

30. Cazorla M, Prémont J, Mann A, Girard N, Kellendonk C, Rognan D. Identification of a low-molecular weight TrkB antagonist with anxiolytic and antidepressant activity in mice. J Clin Invest. 2011;121:1846-57. 
31. Balkowiec A, Katz DM. Activity-dependent release of endogenous brainderived neurotrophic factor from primary sensory neurons detected by ELISA in situ. J Neurosci. 2000;20:7417-23.

32. Garcia N, Tomàs M, Santafé MM, Besalduch N, Lanuza MA, Tomàs J. The interaction between tropomyosin-related kinase $B$ receptors and presynaptic muscarinic receptors modulates transmitter release in adult rodent motor nerve terminals. J Neurosci. 2010;30:16514-22.

33. Kraft AS, Anderson WB, Cooper HL, Sando JJ. Decrease in cytosolic calcium/ phospholipid-dependent protein kinase activity following phorbol ester treatment of EL4 thymoma cells. J Biol Chem. 1982;257:13193-6.

34. Betz A, Ashery U, Rickmann M, Augustin I, Neher E, Südhof TC, et al. Munc13-1 is a presynaptic phorbol ester receptor that enhances neurotransmitter release. Neuron. 1998;21:123-36.

35. Brose N, Rosenmund C. Move over protein kinase C, you've got company: alternative cellular effectors of diacylglycerol and phorbol esters. J Cell Sci. 2002;115(Pt 23):4399-411.

36. Santafé MM, Lanuza MA, Garcia N, Tomàs J. Muscarinic autoreceptors modulate transmitter release through protein kinase $C$ and protein kinase $A$ in the rat motor nerve terminal. Eur J Neurosci. 2006;23:2048-56.

37. Chen $Y$, Tian $Q$. The role of protein kinase C epsilon in neural signal transduction and neurogenic diseases. Front Med. 2011;5:70-6.

38. Ono Y, Fujii T, Ogita K, Kikkawa U, Igarashi K, Nishizuka Y. The structure, expression, and properties of additional members of the protein kinase $C$ family. J Biol Chem. 1988;263:6927-32.

39. Wetsel WC, Khan WA, Merchenthaler I, Rivera H, Halpern AE, Phung HM, et al. Tissue and cellular distribution of the extended family of protein kinase C isoenzymes. J Cell Biol. 1992;117:121-33.

40. Saito N, Itouji A, Totani Y, Osawa I, Koide H, Fujisawa N, et al. Cellular and intracellular localization of epsilon-subspecies of protein kinase $C$ in the rat brain; presynaptic localization of the epsilon-subspecies. Brain Res. 1993;607:241-8.

41. Richter EA, Cleland PJ, Rattigan S, Clark MG. Contraction-associated translocation of protein kinase $C$ in rat skeletal muscle. FEBS Lett. 1987;217:232-6.

42. Cleland PJ, Appleby GJ, Rattigan S, Clark MG. Exercise-induced translocation of protein kinase $\mathrm{C}$ and production of diacylglycerol and phosphatidic acid in rat skeletal muscle in vivo. Relationship to changes in glucose transport. J Biol Chem. 1989;264:17704-11.

43. Antipenko A, Frías JA, Parra J, Cadefau JA, Cussó R. Effect of chronic electrostimulation of rabbit skeletal muscle on calmodulin level and protein kinase activity. Int J Biochem Cell Biol. 1999;31:303-10.

44. Brandman R, Disatnik M-H, Churchill E, Mochly-Rosen D. Peptides derived from the C2 domain of protein kinase C epsilon (epsilon PKC) modulate epsilon PKC activity and identify potential protein-protein interaction surfaces. J Biol Chem. 2007;282:4113-23.

45. Heidkamp MC, lyengar R, Szotek EL, Cribbs LL, Samarel AM. Protein kinase Cepsilon-dependent MARCKS phosphorylation in neonatal and adult rat ventricular myocytes. J Mol Cell Cardiol. 2007;42:422-31.

46. Garczarczyk D, Toton E, Biedermann V, Rosivatz E, Rechfeld F, Rybczynska M, et al. Signal transduction of constitutively active protein kinase $C$ epsilon. Cell Signal. 2009;21:745-52.

47. Arbuzova A, Schmitz AAP, Vergères G. Cross-talk unfolded: MARCKS proteins. Biochem J. 2002;362(Pt 1):1-12

48. Sasaki Y. New aspects of neurotransmitter release and exocytosis: Rhokinase-dependent myristoylated alanine-rich C-kinase substrate phosphorylation and regulation of neurofilament structure in neuronal cells. J Pharmacol Sci. 2003;93:35-40.

49. Matthews VB, Aström M-B, Chan MHS, Bruce CR, Krabbe KS, Prelovsek O, et al. Brain-derived neurotrophic factor is produced by skeletal muscle cells in response to contraction and enhances fat oxidation via activation of AMP-activated protein kinase. Diabetologia. 2009;52:1409-18.

50. Gómez-Pinilla F, Ying Z, Roy RR, Molteni R, Edgerton VR. Voluntary exercise induces a BDNF-mediated mechanism that promotes neuroplasticity. J Neurophysiol. 2002;88:2187-95.

51. Kulakowski SA, Parker SD, Personius KE. Reduced TrkB expression results in precocious age-like changes in neuromuscular structure, neurotransmission, and muscle function. J Appl Physiol. 2011;111:844-52.

52. Pereira DB, Rebola N, Rodrigues RJ, Cunha RA, Carvalho AP, Duarte CB. Trkb receptors modulation of glutamate release is limited to a subset of nerve terminals in the adult rat hippocampus. J Neurosci Res. 2006;83:832-44.

53. Reichardt LF. Neurotrophin-regulated signalling pathways. Philos Trans R Soc Lond B Biol Sci. 2006:361:1545-64.
54. Newton $A C$. Regulation of the $A B C$ kinases by phosphorylation: protein kinase $C$ as a paradigm. Biochem J. 2003;370(Pt 2):361-71.

55. Rybin VO, Sabri A, Short J, Braz JC, Molkentin JD, Steinberg SF. Crossregulation of novel protein kinase $C$ (PKC) isoform function in cardiomyocytes. Role of PKC epsilon in activation loop phosphorylations and PKC delta in hydrophobic motif phosphorylations. J Biol Chem. 2003;278:14555-64.

56. Hansra G, Garcia-Paramio P, Prevostel C, Whelan RD, Bornancin F, Parker PJ. Multisite dephosphorylation and desensitization of conventional protein kinase C isotypes. Biochem J. 1999;342(Pt 2):337-44.

57. Malenka RC, Madison DV, Nicoll RA. Potentiation of synaptic transmission in the hippocampus by phorbol esters. Nature. 1986;321:175-7.

58. Shapira R, Silberberg SD, Ginsburg S, Rahamimoff R. Activation of protein kinase C augments evoked transmitter release. Nature. 1987;325:58-60.

59. Capogna M, Gahwiler B, Thompson S. Presynaptic enhancement of inhibitory synaptic transmission by protein kinases $\mathrm{A}$ and $\mathrm{C}$ in the rat hippocampus in vitro. J Neurosci. 1995;15:1249-60.

60. Hori T, Takai Y, Takahashi T. Presynaptic mechanism for phorbol esterinduced synaptic potentiation. J Neurosci. 1999;19:7262-7.

61. Santafé MM, Garcia N, Tomàs M, Obis T, Lanuza MA, Besalduch N, et al. The interaction between tropomyosin-related kinase $B$ receptors and serine kinases modulates acetylcholine release in adult neuromuscular junctions. Neurosci Lett. 2014;561:171-5.

62. Wierda KDB, Toonen RFG, de Wit H, Brussaard AB, Verhage M. Interdependence of PKC-dependent and PKC-independent pathways for presynaptic plasticity. Neuron. 2007:54:275-90.

63. Rhee JS, Betz A, Pyott S, Reim K, Varoqueaux F, Augustin I, et al. Beta phorbol ester- and diacylglycerol-induced augmentation of transmitter release is mediated by Munc13s and not by PKCs. Cell. 2002;108:121-33.

64. Mochly-Rosen D, Gordon AS. Anchoring proteins for protein kinase C: a means for isozyme selectivity. FASEB J. 1998;12:35-42.

65. Way KJ, Chou E, King GL. Identification of PKC-isoform-specific biological actions using pharmacological approaches. Trends Pharmacol Sci. 2000;21:181-7.

66. Gray MO, Karliner JS, Mochly-Rosen D. A selective epsilon-protein kinase C antagonist inhibits protection of cardiac myocytes from hypoxia-induced cell death. J Biol Chem. 1997;272:30945-51.

67. Csukai M, Mochly-Rosen D. Pharmacologic modulation of protein kinase C isozymes: the role of RACKs and subcellular localisation. Pharmacol Res. 1999;39:253-9.

68. Dorn GW, Souroujon MC, Liron T, Chen $\mathrm{CH}$, Gray MO, Zhou HZ, et al. Sustained in vivo cardiac protection by a rationally designed peptide that causes epsilon protein kinase C translocation. Proc Natl Acad Sci U S A. 1999:96:12798-803.

69. Di-Capua N, Sperling O, Zoref-Shani E. Protein kinase C-epsilon is involved in the adenosine-activated signal transduction pathway conferring protection against ischemia-reperfusion injury in primary rat neuronal cultures. J Neurochem. 2003;84:409-12.

70. Khasar SG, Lin YH, Martin A, Dadgar J, McMahon T, Wang D, et al. A novel nociceptor signaling pathway revealed in protein kinase $C$ epsilon mutant mice. Neuron. 1999;24:253-60.

71. McLachlan EM, Martin AR. Non-linear summation of end-plate potentials in the frog and mouse. J Physiol. 1981;311:307-24.

\section{Submit your next manuscript to BioMed Central and take full advantage of:}

- Convenient online submission

- Thorough peer review

- No space constraints or color figure charges

- Immediate publication on acceptance

- Inclusion in PubMed, CAS, Scopus and Google Scholar

- Research which is freely available for redistribution 